\title{
Towards Exporting Renewable Energy from MENA Region to Europe: An Investigation into Domestic Energy Use and Householders’ Energy Behaviour in Libya
}

\author{
Ahmed M.A. Mohamed ${ }^{\mathrm{a}}$, Amin Al-Habaibeh ${ }^{\mathrm{b}}, \mathrm{Hafez}_{\mathrm{Abdo}}^{\mathrm{c}}$ and Sherifa Elabar ${ }^{\mathrm{d}}$ \\ ${ }^{a \& b}$ Innovative and Sustainable Built Environment Technologies Research Group (iSBET) \\ School of Architecture, Design and the Built Environment \\ ${ }^{a \& c}$ International and Development Research Group (IDERG), Nottingham Business School \\ Nottingham Trent University, Burton Street, \\ Nottingham NG1 4BU, UK \\ ${ }^{d}$ Benghazi University, Libya
}

\begin{abstract}
Renewable energy in Middle East and North Africa (MENA) region, particular solar energy, can be connected to Europe to provide the Northern neighbouring countries with electricity. To achieve this long term objective, it is necessary to understand the local domestic consumption of electricity in the MENA region as the main consumer of energy. The understanding of current and future trends could help to provide a complete picture of the energy situation in MENA region and the feasibility of exporting energy to Europe. For this reason, this paper investigates the domestic energy use and occupants' energy behaviour in Libya. The aim of this study is to evaluate the effect of domestic energy consumption and householders' awareness, attitudes and behaviour on the overall energy consumption in Libya and how this could affect the peak demand, capacity, future trends and government energy budget. The paper also investigates the sustainability aspect of consumer products and the awareness and attitude of consumers towards consumption and demand. A comprehensive survey has been conducted to evaluate several aspects of domestic energy demand and characteristics in Libya. The findings have indicated that there is a significant increase in energy demands in the household sector in Libya and it is significant to have a clear strategy to reduce carbon emission and energy use by improving occupants behaviour as well as utilising other sustainable measures. Minor adjustment in householders' energy consumption behaviour and the technology used to generate energy could provide significant financial
\end{abstract}


savings and contribute significantly to the reduction in carbon emission and energy consumption. This will allow significant benefit to the local economy and the energy sector in Libya but at the same time could provide sustainable energy resources for Europe on the long term.

Keywords: MENA region, Libya, renewable energy, occupants' behaviour, energy consumption, domestic appliances.

\section{Introduction}

Renewable energy and energy demand in Middle East and North Africa (MENA) region can be closely linked to Europe. Several visions has been put in place in the past to power Europe from the renewable energy in Africa, particularly North African countries including Libya. For example, DESERTEC was developed by the Trans-Mediterranean Renewable Energy Cooperation (TREC) [1]. Research suggests that the desert sun could be used to meet increasing power demand in the MENA region and further to provide clean energy to Europe. A main benefit of renewable energy is that it reduces carbon emissions across the EU-MENA region and powers desalination plants to provide freshwater to the MENA region. For this vision to become a reality, it is important to understand the local energy demand and consumption in the MENA region, this is to determine if sufficient renewable energy may be generated and exported to Europe. In this paper, Libya is used as an example to highlight the expected energy demand and domestic energy use alongside potential renewable energy generation from MENA region.

Although the focus of this paper is on Libya, it has significant implementations and impact on other countries in relation to applied energy practices and implementations. Libya is similar in culture and style of living to many other countries around the world, particularly within the MENA region. The impact of this paper will be extremely important for those countries and scientific researcher in the field of applied energy.

Libya occupies a strategic location in the MENA region since it is located in a place that connects the Southern Europe with the rest of Africa and the Eastern with the Western Africa. Libyan hydrocarbon reserves are the largest in Africa and ranked the fifth largest in the world. Thus, Libya plays a major role in providing petroleum and electricity to international networks [2]. Electricity generation between the years of 2000 and 2010 has been doubled in 
Libya. However, increasing power demand over the production capacity have led to electricity shortfalls, therefore the country suffers from power outages in main cities and other provinces. It is anticipated that Libyan electricity demand will increase more than two and half folds by the end of 2020 [3]. In addition, the current political instability in the country and the power supply issues have their significant effect on oil and gas production from some of the country's largest oil field [4]. Therefore, this paper focuses on how domestic energy consumption behaviour affects the overall electricity consumption and demand in Libya. This study introduces, almost for the first time, a scientific investigation into the effects of the Libyan consumer behaviour on the overall consumption and demand of energy in Libya and this by large is of interest for local and foreign investors.

Domestic energy use in Libya accounts for about 36\% of the total energy consumption [5]. Consumption of domestic energy depends on family size, lifestyle, environment (location and climate), types of appliance in use, ownership, physical characteristics of the house and human behaviour [6-10]. Therefore, investigating the effects of these characteristics and the possibility of altering them on the overall energy consumption and demand in Libya is worth undertaking; and this is in fact represents the objective of this research study.

Over the years, the Libyan energy sector has undergone development on different aspects such as design, materials and installation. However, research on energy use and energy consuming behaviour is relatively new in Libya. To date, building energy efficiency of houses which can limit cold and heat transfer due to improved thermal insulation, and improved construction is not a well investigated matter in Libya [3]. Moreover, it seems not to be of much interest in the establishment of the average Standard Assessment Procedure (SAP) rating of houses by the Libyan government and most of Libyan people. Energy performance of a building depends on a number of factors such as the climate, insulation of ceiling and walls, infiltration, efficiency of cooling and/or heating systems (which is a function of type of air-conditioning systems, boiler and boiler's fuel types), type of glazing, home or floor area, orientation, type of construction, age of house, number of windows and shading on home's structure. The overall life-cycle domestic energy consumption is lower in a housing stock constructed with low-embodied energy materials [10-11], and orientated for solar gain by windows and heavily insulated fabric in a moderate climate [12].

Home energy use (domestic) is a function of the structure and intensity of energy use in that home [7]. Energy-intensity is affected by use of energy-intensive appliances, cooling and 
heating demand, standards of living, occupancy work patterns, comfort expectations, energy use behaviour, types and frequency of use of appliances and cultural habits [3, 9-11].

Domestic energy use can be reduced by natural ventilation and lighting, minimising cooling and heating loads, efficient domestic appliances, and promoting energy- conscious behaviour [13]. At the same time, this reduction can lead to a reduction in peak load of the country. Domestic energy use is increasing in Libya due to the increase in the number of dwellings which is in turn leads to an increase in electricity usage. However energy-saving measures are not adopted and this can affect significantly household energy efficiency in Libya [14]. Therefore, carbon dioxide emissions (CO2) have continuously increased without suitable appraisal of new energy-saving information [15].

This study takes into consideration previous international studies that have been conducted in other countries [6, 9, 16-19]. However it differs from them as being applied to Libya: a key oil and natural gas producing country. Based on the authors' search and Libyan government records, this study is one of the first research studies in this area in Libya and in fact is a part of an on-going research programme.

This paper is aiming at investigating the effects of domestic households' energy consumption and awareness, attitudes and behaviour on the overall energy consumption in Libya and how this affect the peak production, capacity and state budget.

\section{Household energy use and energy behaviour}

In the UK, as well as in other countries, studies have been conducted to investigate the factors that affect domestic energy efficiency and domestic energy consumptions [6, 9, 16-19]. The techniques used to conduct these studies varied to include questionnaires [20], temperature measurements, electricity metre readings and personal interviews [21-22] gathering information from utility bills; and monitoring of individual household appliances [9, 23]; self-recording energy diaries [24] energy audits [25-26].

In this paper, energy behaviour refers to actions taken by occupants in their use of energy in their houses. Energy behaviour plays an important role in determining the magnitude and pattern of domestic energy use as has been presented by a number of researchers representing a number of disciplines including economy, science, environmental psychology, business and social policy [27-30]. Total consumption of domestic energy can be reduced by 10 to $30 \%$ by 
changing-householders' energy consumption behaviour [21, 31-32]. According to Firth et al (2008) [33], a study related to dwellings in the UK has demonstrated that overall electricity consumption is accounted for a $10.2 \%$ increase in consumption by standby appliances (e.g. consumer electronics and TV) and almost $4.7 \%$ increase in consumption of active appliances (e.g. electric showers, lighting and kettles) [33]. Seeking behavioural modifications with the aim of reduction of energy consumption involves some interactions of technical and social phenomena [34].

With regard to energy use and behaviour, three aspects worth narrating here: purchase usage, maintenance and behaviour-related [9, 34]. Also, education level and awareness of energy efficiency and climate change contribute to energy saving behaviour. Furthermore, many people do not understand their energy bills, and others do not know how and where they may save energy. (These classifications and considerations have been used in the questionnaire of this study).

Purchase-related behaviour contains the energy characteristics of the products chosen and describes why householders change their characteristics, for example, by adding thermal insulation, installing low-energy light bulbs, energy efficient glazing, preventing draughts, monitoring energy consumption and/or generating own energy.

A strong relation has been established by Yohanis (2008) [21] between floor area and average annual electricity consumption concluding that more floor area leads to greater electricity usage [21]. Druckman and Jackson (2008) [35], studied domestic energy usage at all levels of society; they have identified factors that contribute to control the energy usage as: type of house, household composition, tenure and location (whether countryside or city) [35]. Revenue is a significant factor affecting energy use, however the fact that the relation of income to education and awareness of environmental matters is not straight forward, making the relationship between income and energy use complex [36-38]. One main factor in the reduction of household energy consumption is the availability of suitable information. There have been significant attempts by government bodies, electricity utilities (e.g. NIE, 2011) [39], national and local energy-saving schemes to offer information concerning energy reduction measures and promotion of renewable energy (e.g. Action Renewables, 2011) [40] of which the efficiency is different. Antecedent (prior to consumption) and response (about current consumption) information and motivations are more effective in combination; but the removal of response and motivations often leads to a return of energy usage to former levels 
while sometimes energy preservation based on information only may continue, and properly delivered direct information might be an essential source of future energy-efficiency gain [9, 41].

Dietz (2010) [42] argues matters related to the narrowing of energy-efficiency gap in the USA where householders are unsuccessful to benefit from the opportunity to save energy and show their part in conserving the environment [42]. Jaffe and Stavins (1994) [43] state that there is a gap between real and ideal energy use. They use the ideas of 'market failure' and 'non-market failure' to clarify the slow distribution of energy-efficient technologies; 'market failures' is defined as market barriers that may explain a policy intervention to overcome them. Their effort is a sign of how complex household energy analysis which includes technical, economic and social disciplines, and the assumptions policy makers require to make [43]. Gillingham et al. (2009) [44] define the requirement to recognise the economically effective level of energy-efficiency, and whether particular policy is essential to accomplish it. They identified behavioural and market failures that might assist to clarify the gap [44]. Carrico et al. (2011) [30] have described the absence of available brief summary for policy makers of the key results of social and behavioural science studies on household energy behaviour. They stipulate that to maximise the potential for achievement, policy makers must combine multiple approaches to behaviour alteration, such as measures to decrease cognitive costs, raise motivation, and offer more actionable and related information. In the vast majority of cases, a single approach to altering behaviour, such as availability of information, is not adequate to induce meaningful levels of behaviour change, and consequently, a number of strategic tools are required to be in place in order to target a wider audience and to boost larger rates of acceptance [30].

\section{Methodology}

\subsection{Methodological Approach}

This work has been conducted by means of a general population survey using a statistically significant sample and number of self-completed questionnaires in different locations across Libya. The self-completed questionnaire technique has been constructed. The questionnaire, in Arabic, was delivered by hand to every respondent and collected later. The questionnaire which is used in this paper as the main data collection method directed at a sample of energy consumption in Libya, to produce representative findings that can be generalised to Libyan 
energy users. It has been designed to investigate the main drivers that affect domestic energy use: residence, physical characteristics of houses and residents' energy behaviour (which includes awareness of energy saving measures and attitudes) to saving energy. The questionnaire has been selected in this paper because it permits the authors to achieve more details and obtain greater depth of knowledge about what being investigated, particularly for quantitative and qualitative analyses; also it allows reaching a wider participant population at least compared to interviews. For this paper, a reasonable sample of the population has been selected and their demographic variables defined. The survey was carried out during the year of 2013, and it included some pictures to increase the clarity and to simplify the selection process between the questionnaire answers for the respondents. In order to decide which households are used for the study sample, the current investigation used a stratified random sampling which is divided into non-overlapping groups, i.e. geographical areas across Libya. In addition, electricity consumption data has been obtained to study the total domestic consumption in Libya and to cross reference the findings of the survey as necessary.

\subsection{Demographic variables}

From a total survey of 823 questionnaires distributed in the study area see Table 1, 429 valid questionnaires have been received which shows that 52\% response rate has been achieved (41 questionnaires have been rejected due to incompletion). The data has been collected taking into consideration other studies in other countries [9, 45].

Table 1: Sample Distribution.

\begin{tabular}{|c|c|c|c|c|c|c|c|}
\hline & \multirow{2}{*}{$\begin{array}{c}\text { Total } \\
\text { User type }\end{array}$} & \multicolumn{6}{|c|}{ Regions } \\
\cline { 3 - 8 } & Lribya) & Tripoli & Benghazi & $\begin{array}{c}\text { Western } \\
\text { region }\end{array}$ & $\begin{array}{c}\text { Middle } \\
\text { region }\end{array}$ & $\begin{array}{c}\text { Southern } \\
\text { region }\end{array}$ & $\begin{array}{c}\text { Green } \\
\text { Mountain }\end{array}$ \\
\hline $\begin{array}{c}\text { Number of } \\
\text { residential } \\
\text { houses }\end{array}$ & 905,970 & 317,347 & 147,569 & 187,017 & 135,475 & 53,669 & 64,893 \\
\hline $\begin{array}{c}\text { Krejcie } \\
\text { Distribution } \\
\text { (based on 5\% } \\
\text { degree of } \\
\text { accuracy) }\end{array}$ & $\mathbf{3 8 4}$ & $\mathbf{1 3 5}$ & $\mathbf{6 3}$ & $\mathbf{7 9}$ & $\mathbf{5 7}$ & $\mathbf{2 3}$ & $\mathbf{2 7}$ \\
\hline $\begin{array}{c}\text { Number of } \\
\text { questionnaires } \\
\text { received and } \\
\text { valid }\end{array}$ & $\mathbf{4 2 9}$ & $\mathbf{1 1 3}$ & $\mathbf{6 6}$ & $\mathbf{8 6}$ & $\mathbf{8 5}$ & $\mathbf{3 5}$ & $\mathbf{4 4}$ \\
\hline
\end{tabular}


Table 2 presents the occupancy characteristics of the surveyed houses. The sample in this study comprises different types of household. A large percentage in this study includes single flat houses or double flats houses as they are common houses in the study area where private apartments or government's dwellings, often had 1, 2 or 3 bedrooms. The sample, both in terms of characteristics and size, is considered to be a reasonable representative of current dwelling types in Libya.

Table 2: Occupancy characteristics of the surveyed houses.

\begin{tabular}{|c|c|c|c|}
\hline $\begin{array}{c}\text { Number of bedrooms per } \\
\text { household }\end{array}$ & $\%$ & Number of occupants & $\%$ \\
\hline 1 & $18 \%$ & 1 & $1 \%$ \\
\hline 2 & $23 \%$ & 2 & $10 \%$ \\
\hline 3 & $39 \%$ & 3 & $31 \%$ \\
\hline 4 & $19 \%$ & 4 & $6 \%$ \\
\hline 5 & $7 \%$ & 5 & $3 \%$ \\
\hline $6+$ & $1 \%$ & $6+$ & $49 \%$ \\
\hline Household income LD & $\%$ & $\begin{array}{l}\text { Employment status of } \\
\text { primary householder }\end{array}$ & $\%$ \\
\hline$<300$ & $10 \%$ & Employed & $30 \%$ \\
\hline $300-500$ & $25 \%$ & Unemployed & $8 \%$ \\
\hline $500-1000$ & $35 \%$ & Retired & $22 \%$ \\
\hline $1000-5000$ & $29 \%$ & Child & $25 \%$ \\
\hline$>5000$ & $1 \%$ & Others & $15 \%$ \\
\hline Age of primary householder & $\%$ & $\begin{array}{c}\text { Average age of all } \\
\text { householders }\end{array}$ & $\%$ \\
\hline$<30$ & $3 \%$ & $<30$ & $41 \%$ \\
\hline $31-50$ & $46 \%$ & $31-50$ & $36 \%$ \\
\hline $51-70$ & $32 \%$ & $51-70$ & $20 \%$ \\
\hline $70+$ & 19\% & $70+$ & $3 \%$ \\
\hline
\end{tabular}

\subsection{General observations}

There are significant differences between the average number of occupants per householders in the UK and Libya since the average in Libya is 4.5 per household compared to 2.61 for the 
UK [9]. Three or six (31\%-49\%) tenants per household are the majority of the sampled households in Libya; only $20 \%$ of the sampled households have single, couples, four or five occupants.

The majority of primary occupants are between 31 to 50 years old and an important proportion of the respondents are in the retirement age, with $19 \%$ over 70 years old and only $3 \%$ of primary occupants surveyed are under 30 years old. When all the occupants are considered, $3 \%$ are over 70 years of age and $41 \%$ under the age of 30 . This is an essential piece of information since those younger age groups may hold different opinions or attitude towards energy use.

The results demonstrate that $8 \%$ of the occupants in homes surveyed are unemployed and $22 \%$ are retired. The 'other' $15 \%$ group includes housewives and students involving singleparent families. Few students are primary occupants of houses. All employment occupants are representative of the general population, with a broad range of occupations. The yearly household income has been divided into 5 income brackets. The results are based on 429 households as 45 homes did not wish to disclose their income. 139 of the surveyed households have low income; due to the households are permanently disabled and/or being pensioners. The sample also included 36 from higher income ranges. The various income groups in the study are considered to be a reasonable representation of the wider population.

\subsection{The significance of the research}

The domestic sector is an important contributor to energy consumption in world's energy. In USA direct electricity use accounts for more than half of the energy consumed, while in Sweden approximately $20 \%$ of the total annual consumption of electricity is in fact of domestic nature (appliances, lighting, etc.) [46]. A significant body of research has been undertaken in the UK on domestic electricity consumption [47]. In this respect, with higher domestic energy use in MENA, energy production continues to increase, but not as fast as local energy demand. In 2006 energy output was about 47\% higher than in 1990, while the use of energy in the area subsidized in many countries more than doubled. The growth of energy use (about $4.3 \%$ a year) was the highest of any region. In 1990, energy use constituted $34 \%$ of the region's production by 2006, $47 \%$ of MENA energy production was domestically consumed [48]. Approximately one-half of total energy subsidies in MENA are accounted for by petroleum products, while the remainder represents subsidies on electricity and natural gas. There is a wide dispersion of subsidies in the region, with subsidies being more prevalent in 
oil exporters [49]. Indeed, since the oil crisis in the 1970s domestic energy conservation has been an area of investigation for applied social and environmental research [46]. In particularly, according to the results of Geun Young Yun (2011), there are close links between occupants, the building, appliances and behaviour factors and household energy consumption. In addition the same study confirms that there are relationships between demographic and economic factors and household energy use [10]. Therefore this paper focuses on investigating the effects of domestic energy use and householders' energy behaviour on the overall energy consumption in Libya. It focuses on the structure and intensity of domestic energy use, and it studies householders' awareness of energy issues, attitudes to the reduction of energy consumption and general energy behaviour of householders. The results of this research study must be of particular importance to a number of stakeholders; energy producers and investors in the energy sector, policy makers, national planners, Libyan households, prospective researchers to name a few.

\section{Result and discussion}

\subsection{Electricity demand and load variation in Libya}

Since our focuse is directed to the relationship between energy consumption behaviour by Libyan households and the overall energy demand in Libya, it is reasonably important to find the extent of the link between the electrical local loads and householders counsumpation patterns in Libya. In this regard, generaly most months in Libya are hot with a mean temperature exceeding $35^{\circ} \mathrm{C}$ in Eastern regions and could reach over $50^{\circ} \mathrm{C}$ in the south during the hottest months of the year. Likewise in winter, the temperature could fall below $0^{\circ} \mathrm{C}$ and this is associated with a high rate of electricity consumption [2, 50]. The fact that the government heavily subsidises current consumption cost is leading to rapid energy demand with customers paying one-third of the cost per $\mathrm{kWh}$ [2-3]. The total electricity generation by General Electricity Company of Libya (GECOL) in 2012, which produced electricity from 14 main power stations in the country, has been about 33,980 GWh and it has costed circa 6 billion $\mathrm{m}^{3}$ of natural gas, 2.3 Million $\mathrm{m}^{3}$ of light fuel oil and 805 thousand $\mathrm{m}^{3}$ of heavy fuel oil [51-53]. GECOL has difficulties in meeting the increaesd electricity demand; hence power shortages are starting to necessitate programmed electricity cuts in several cities including, among others, Tripoli the capital and Bengazhi the second largest city for a period of 6 hours per day or more [54]. One of the most important issues which is a challenge to the load management engineers in each electrical energy system is electrical load forecasting. 
The data obtained from GECOL during the authors' visit to Libya is presented in Figure 1. Figure 1 demonstrates the peak load of the general network in Libya during the period 20022013 with annual increase rate of about 10\%, taking into consideration the drop in consumption in 2011; This load includes households and other sectors. The Figure also depicts data about power electrical demand forecasts and expansion in production during the period 2013-2020, these last data are based on strategic studies by GECOL. The peak load is about 6,062 MW, 36\% of which relates to domestic household consumption.

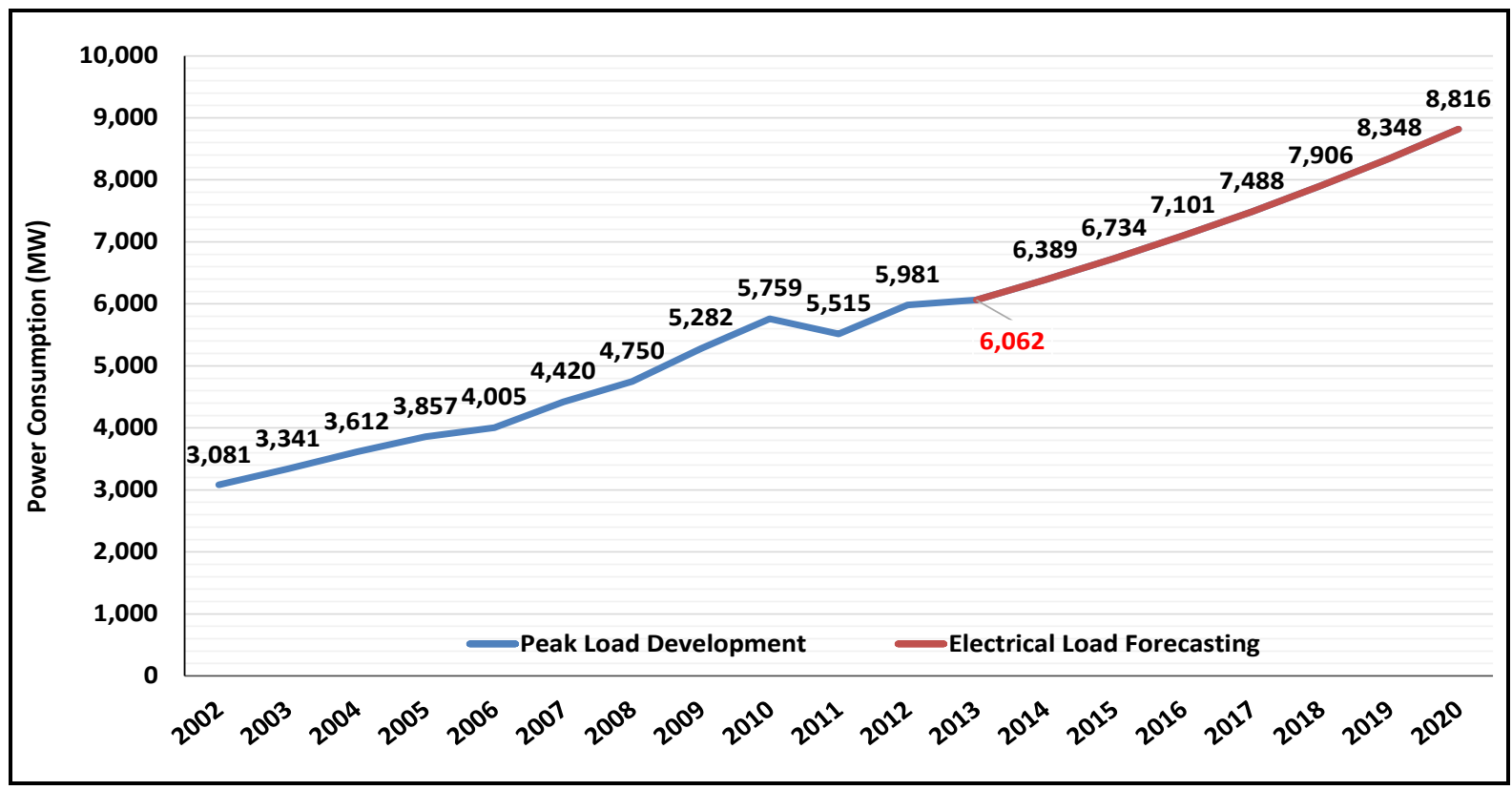

Figure 1: Electrical peak load demand and forecasting; data source: [3].

According to the Information and Planning Department at GECOL, several factors involved in the load forecasting system which have political, climatic, demographic and economic aspects. It is noticed from Figure 1 that the peak load of electricity is increasing gradually, and the possibility of increasing the capacity of existing plants is not economically viable as they need significant expensive maintenance and upgrading. In addition, the establishment of new plants requires time and considerably significant investments which is one of the many problems facing the current government in Libya at the moment. Energy insecurity is an existing problem in Libya and ongoing to fester since many areas experiencing a real crisis as a result of complete or relative absence of electricity. Therefore, the study of the behaviour of the energy consumers and the effort to change it can be an essential part of the solution to the problem of energy security and this can lead to the reduction in peak load of electricity and public spending on energy. Energy waste reduction in certain places, such as cities, can help the government to redistribute the available energy to areas in need of energy. Figure 2 
illustrates the monthly variation of the Libyan electrical load and the average readings of temperature in the year 2012 as an example. The data in Figure 2 has been provided by Information and Planning Department at the GECOL which shows an increased peak load during winter and summer seasions, these are months 12, 1, 2 and 3 for winter and 6, 7, and 8 for summer. Figure 2 shows also a decrease in monthly loads during spring and autumn (months 3, 4 and 5) and (months 9, 10 and 11) respectively. This is a clear indication that signficant energy is used for space heating and air conditioining applications.

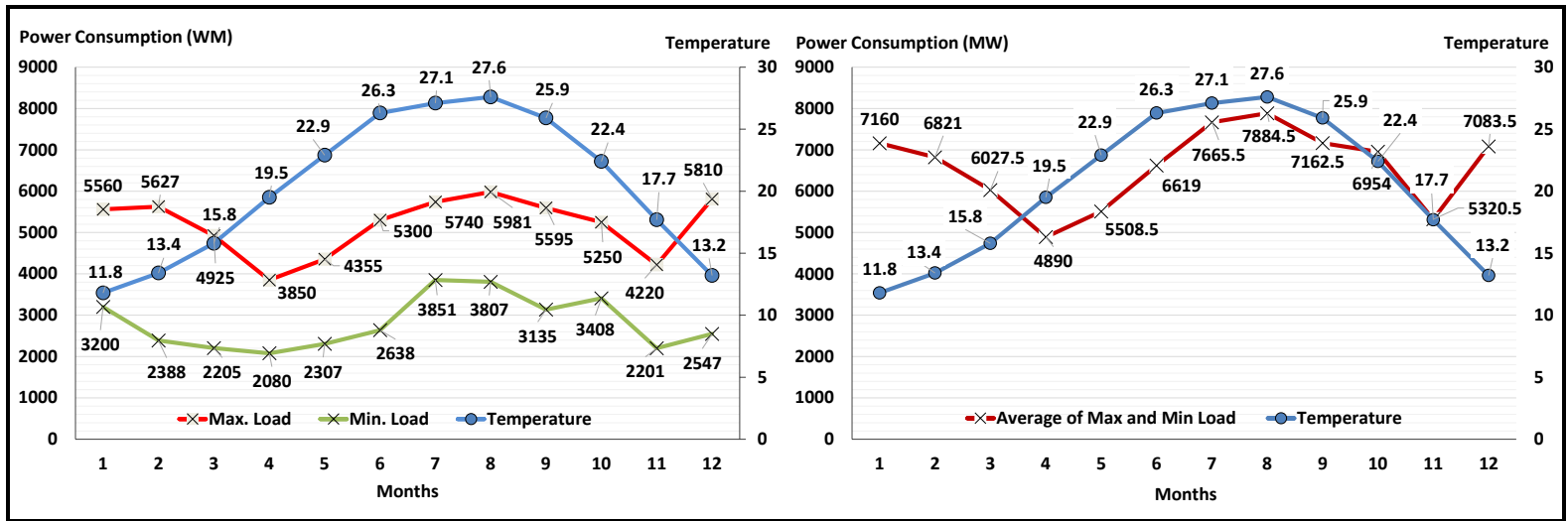

Figure 2: The monthly load and the average of the temperature as in 2012; data source: [3, 55].

The following sections present the results of our survey. In order to estimate financial cost of the energy use of a given appliance the authors used the Libyan Electricity Tariff shown in Table 3.

Table 3: Libyan Electricity Tariff [5].

\begin{tabular}{|l|l|}
\hline \multicolumn{2}{|c|}{ Residential } \\
(According to General Electricity company ) \\
\hline Consumption level (kWh) & Tarif (Dirham/ kWh) \\
\hline 1 to 1000 & 20 \\
\hline 1001 to 1400 & 30 \\
\hline Over 1400 & 50 \\
\hline
\end{tabular}

Note: 1 LD = 1000 Dirham $\approx 0.5$ GB

\subsection{Cooling, Heating and hot water supply systems}

Air-conditioning, space heating and hot water supply are three major areas of domestic households energy consumption. The characteristics of the cooling, heating systems, types, age and frequency of supplementary cooling and heating, controllers for immersion heaters, 
shower facilities and method of water heating in the respondents' dwellings are demonstrated in Table 4. A significant implication of the statistics in Table 4 is that air conditioning systems in Libya are found to be $100 \%$ electrical, this implies a requirement for a significant electricity supply to meet the demand arising from the air conditioning system in Libya for both cooling and heating purposes.

In terms of frequency of use of cooling systems in summer, $60 \%$ of householders use it most of the time; while in winter only $9 \%$ use cooling most of the time. For heating systems it is used $55 \%$ most of the time during winter but only $13 \%$ most of the time. These statistics support our assumption that peak load is driven most by the increased heating and cooling needs during winter and summer seasons, as indicated on a macro scale in Figure 2.

Table 4: Air conditioning and heating systems in the 429 surveyed homes.

\begin{tabular}{|c|c|c|c|}
\hline $\begin{array}{l}\text { Type of domestic air- } \\
\text { conditioning system }\end{array}$ & $\%$ & $\begin{array}{l}\text { Types of energy for air- } \\
\text { conditioning }\end{array}$ & $\%$ \\
\hline $\begin{array}{c}\text { Central air-conditioning system: } \\
\text { multi-split-systems }\end{array}$ & $1 \%$ & Oil & 0 \\
\hline $\begin{array}{l}\text { Central air-conditioning system: } \\
\text { ducted systems }\end{array}$ & $40 \%$ & Gas & 0 \\
\hline $\begin{array}{l}\text { Split unit room air-conditioning } \\
\text { system }\end{array}$ & $55 \%$ & Electric & $100 \%$ \\
\hline Portable air-conditioning system & $1 \%$ & \multirow{2}{*}{ Coal fire } & \multirow{2}{*}{0} \\
\hline none & $3 \%$ & & \\
\hline $\begin{array}{l}\text { Frequency of use of cooling in } \\
\text { summer }\end{array}$ & $\%$ & $\begin{array}{l}\text { Frequency of use of cooling } \\
\text { in winter }\end{array}$ & $\%$ \\
\hline Few times & $36 \%$ & Few times & $20 \%$ \\
\hline Most of time & $60 \%$ & Most of time & $9 \%$ \\
\hline Once a week & 0 & Once a week & 0 \\
\hline Never & $8 \%$ & Never & $71 \%$ \\
\hline Age of air-conditioning systems & $\%$ & Types of energy for heating & $\%$ \\
\hline$<5$ year & $25 \%$ & None & $3 \%$ \\
\hline 5-10 years & $67 \%$ & Gas & $10 \%$ \\
\hline \multirow{3}{*}{$15+$} & \multirow{3}{*}{$8 \%$} & Coal fire (charcoal) & $1 \%$ \\
\hline & & oil & $5 \%$ \\
\hline & & Electric & $81 \%$ \\
\hline $\begin{array}{l}\text { Frequency of use of heating in } \\
\text { summer }\end{array}$ & $\%$ & $\begin{array}{l}\text { Frequency of use of heating } \\
\text { in winter }\end{array}$ & $\%$ \\
\hline Never & $41 \%$ & Never & $3 \%$ \\
\hline
\end{tabular}




\begin{tabular}{|c|c|c|c|}
\hline Few times & $44 \%$ & Few times & $42 \%$ \\
\hline Most of the time & $13 \%$ & Most of the time & $55 \%$ \\
\hline Once a week & $2 \%$ & Once a week & 0 \\
\hline $\begin{array}{l}\text { Types of building heating } \\
\text { system }\end{array}$ & $\%$ & Age of heating system & $\%$ \\
\hline $\begin{array}{l}\text { Cooling and heating with } \\
\text { Central Air-conditioners }\end{array}$ & $33 \%$ & $<5$ year & $41 \%$ \\
\hline Gas heater & $12 \%$ & 5-10 years & $44 \%$ \\
\hline $\begin{array}{l}\text { Cooling and heating with split } \\
\text { units air-conditioning systems }\end{array}$ & $49 \%$ & $15+$ & $15 \%$ \\
\hline others & $6 \%$ & Age of heating system & $\%$ \\
\hline $\begin{array}{l}\text { Method of kitchen/bathroom } \\
\text { taps water heating }\end{array}$ & $\%$ & $\begin{array}{l}\text { Types of control for } \\
\text { immersion heaters }\end{array}$ & $\%$ \\
\hline Central heating system & 0 & $\begin{array}{l}\text { Thermostat with } \\
\text { Timer/programmer }\end{array}$ & $2 \%$ \\
\hline Immersion heating & $97 \%$ & Thermostat & $97 \%$ \\
\hline Gas heater & $1 \%$ & \multirow{2}{*}{ On/off control only } & \multirow{2}{*}{$1 \%$} \\
\hline others & $2 \%$ & & \\
\hline \multicolumn{2}{|l|}{ Shower facilities } & \multicolumn{2}{|l|}{$\%$} \\
\hline \multicolumn{2}{|c|}{ Instant Electric shower } & \multicolumn{2}{|l|}{$1 \%$} \\
\hline \multicolumn{2}{|c|}{ Immersion heater shower } & \multicolumn{2}{|l|}{$99 \%$} \\
\hline
\end{tabular}

Data in the above table shows that the majority of homes surveyed use immersion heaters to heat water, this is an area that the Libyan government need to consider in order to cut down on energy consumption. There is a need to use heating from solar technologies or heat pumps to reduce both wastage of energy and peak load. Especially many studies have shown the feasibility of utilisation of renewable energy technologies in Libya, see for example [3]. However, whilst it is understood that solar energy works effectively during summer other renewable energy options, such as wind and waste-to-energy may be ideal alternatives during winter.

\subsection{Domestic appliances}

With the improvement in the living style in Libya, there has been an increasing need to use fridge-freezers, dishwashers, microwave, microwave ovens, electric ovens, electric kettle, electric cooker, and tumble driers in households. Figure 3 shows the possession of various domestic appliances in the current surveyed households (full details are provided in Appendix 
1). There has been growing number in the households with multiple television sets, DVD players and computers.

There seems to be an increase in the number of appliances used in Libyan houses at the time of the survey (2013) compared to the previous five years; for example $26 \%$ of homes have DVD players in comparison to the past five years where only $13 \%$ had one. Computers also increased from $22 \%$ five years ago to $84 \%$ during the time of the survey. The percentages of households which owned multiple TV sets has witnessed a significant increase over the last five years. This increase in TV sets has a significant effect on electricity peak load, not only in relation to the consumption of TVs but the other social aspects and the use of airconditioning and lighting systems in different rooms. Raising energy efficiency and conservation cultures among Libyans along with depending on renewable energy options should collectively aid the objectives of Libyan energy security and cutting on CO2 emissions.

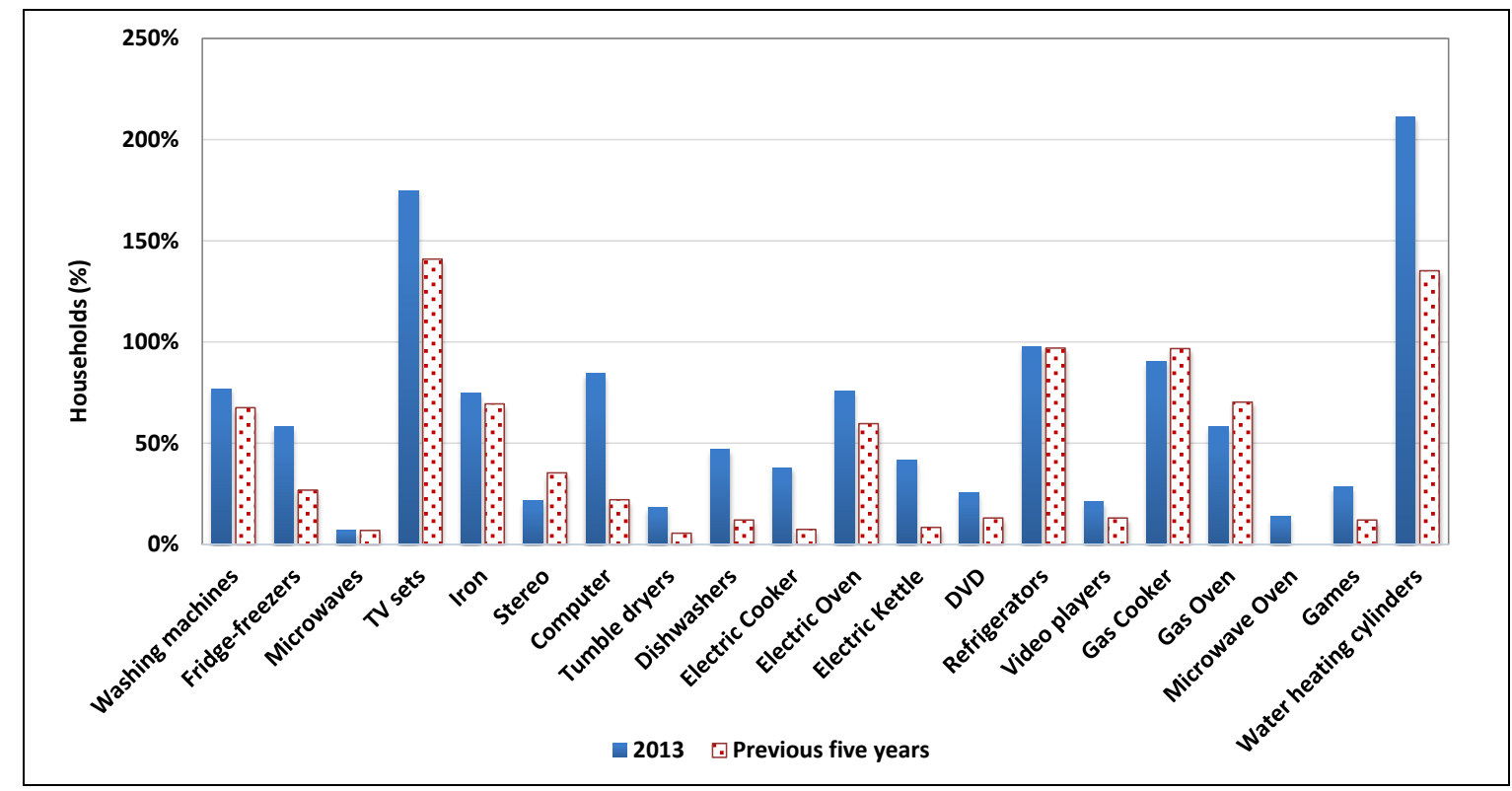

Figure 3: The number of appliances (a comparison between 2013 (current) and previous 5 years).

Table 5 demonstrates that the majority of household appliances have been purchased in the past 5 years. There are consequently, possibilities to purchase energy efficient appliances had buyers been made aware of energy issues linked with the rating of appliances, and if they had chosen to do so. The table shows that there is an increase in purchasing electric cooker, oven and kettle, 76\%, 81\% and 87\% respectively. On the other hand, there has been a remarkable decrease in purchasing of gas cookers and ovens (36\% and 39\% respectively). Since the government's trend is towards high rise building (tower) without the use of gas network (i.e. 
the use of gas cylinders), people find the use of electric appliances easier than gas appliances and this is safer in tower buildings; this is in fact another pressing factor from the demand side for electricity in Libya and must be met by sufficient supply, otherwise energy insecurity will be clearly and severely present in Libya.

Table 5: Number of appliance expressed in percentage in different age-brackets.

\begin{tabular}{|l|l|l|l|l|l|}
\hline \multirow{3}{*}{ Name of appliances } & \multicolumn{5}{|l}{$\begin{array}{l}\text { Age-brackets(years) } \\
\text { Numbers of appliances \% }\end{array}$} \\
\cline { 2 - 6 } & $<\mathbf{0 . 5}$ & $\mathbf{1 - 2}$ & $\mathbf{3 - 5}$ & $\mathbf{5 - 1 0}$ & $\mathbf{1 1 +}$ \\
\hline Washing machines & 28.4 & 12.5 & 25.8 & 18.6 & 14.7 \\
\hline Fridge-freezers & 17.6 & 21.7 & 33.6 & 21.5 & 5.6 \\
\hline Microwaves & 12.3 & 16.5 & 25.9 & 33.5 & 11.8 \\
\hline TV sets & 35.9 & 25.6 & 19.5 & 16.2 & 2.8 \\
\hline Iron & 17.5 & 21.9 & 25.3 & 12.4 & 22.9 \\
\hline Stereo & 0 & 0 & 5.3 & 21.1 & 73.6 \\
\hline Computer & 31.1 & 25.3 & 33.1 & 9.2 & 1.3 \\
\hline Tumble dryers & 22.9 & 15.2 & 18.9 & 10.2 & 32.8 \\
\hline Dishwashers & 14.1 & 15.2 & 15.6 & 22.5 & 32.6 \\
\hline Electric Cooker & 25.3 & 28.6 & 22.3 & 12.6 & 11.2 \\
\hline Electric Oven & 32.3 & 26.9 & 21.5 & 14.6 & 4.7 \\
\hline Electric Kettle & 32.9 & 29.6 & 24.6 & 10.6 & 2.3 \\
\hline DVD & 12.6 & 25.6 & 24.1 & 21.2 & 16.5 \\
\hline Refrigerators & 12.6 & 28.6 & 22.1 & 16.9 & 19.8 \\
\hline Video players & 21.6 & 23.6 & 16.8 & 25.4 & 12.6 \\
\hline Gas Cooker & 4.4 & 11.6 & 19.5 & 21.9 & 42.6 \\
\hline Gas Oven & 6.3 & 12.5 & 19.8 & 33.5 & 27.9 \\
\hline Microwave Oven & 0 & 15.6 & 28.7 & 21.8 & 33.9 \\
\hline Games & 25.8 & 21.3 & 23.4 & 16.3 & 13.2 \\
\hline Immersion heater & 3.6 & 11.4 & 24.8 & 25.3 & 34.9 \\
\hline
\end{tabular}

\subsection{Householders' knowledge of energy rating of appliances}

This section discusses what the Libyan households think about the rating of their appliances. Figure 4 demonstrates that $91 \%$ of householders did not recognise the energy rating of their appliances. Possible clarifications could be related to the fact that the energy expenditure to income ratio is low enough for many people to drive their attention away from thinking of energy efficiency and conservation. Also, possible relative affluence in society; lack of energy efficiency and energy rating of appliances; lack of government regulation and ineffective energy information communication are among the reasons that Libyan households are not well educated on energy rating of their appliances $[9,56]$. In support of our argument, statistics in Table 6 shows that the vast majority of the surveyed householders have indicated 
that price, brand and reliability are the main factors in the selection of a new appliance; minority of householders cited energy rating as the main factor.

\section{Are you aware of your household appliances energy rating ? 429 total responses}

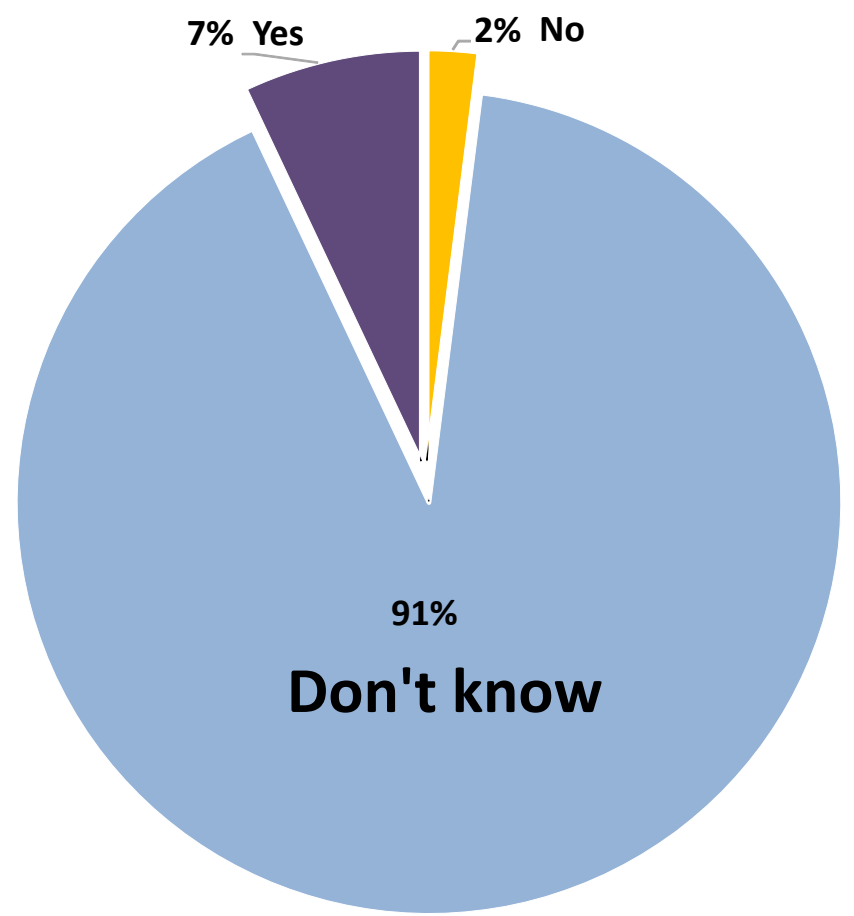

Figure 4: Households thoughts of the rating of their household appliances.

Table 6: Factors that affect purchase of household appliances.

\begin{tabular}{|l|l|}
\hline Factors that affect purchase of household appliances & Importance \\
\hline Price & $39 \%$ \\
\hline Brand & $17 \%$ \\
\hline Reliability & $15 \%$ \\
\hline Brand and price & $12 \%$ \\
\hline Price and energy rating & $11 \%$ \\
\hline Energy rating & $3 \%$ \\
\hline Never energy rating & $2 \%$ \\
\hline Other & $1 \%$ \\
\hline
\end{tabular}

\subsection{Energy consumption behaviour by Libyan household.}

There is no big difference between the number of night and day hours in Libya during the year. However, summer is characterised by dry wind and warm temperatures accompanied with dust most of the time; while in winter there is reduction in temperature and possible rain. 
Figure 5 demonstrates the frequency of using washing machines, tumble driers, electric cooker and irons in the surveyed homes between winter and summer. The usage of tumble driers in winter is higher than in the summer, while in the case of the washing machines, the frequency of use continued almost the same during the year. Furthermore, the frequency of using electric cookers per week in the summer is more than in winter, but the use of the iron is almost the same in both seasons. Although, there is frequent dust during the summer time, the frequency of using drying line in summer is more than in winter. In both winter and summer the average number of times washing machines are used per week per household are 3.81 and 3.18 respectively. Some homes use their washing machines over 10 times per week and their tumble driers up to 10 times per week.

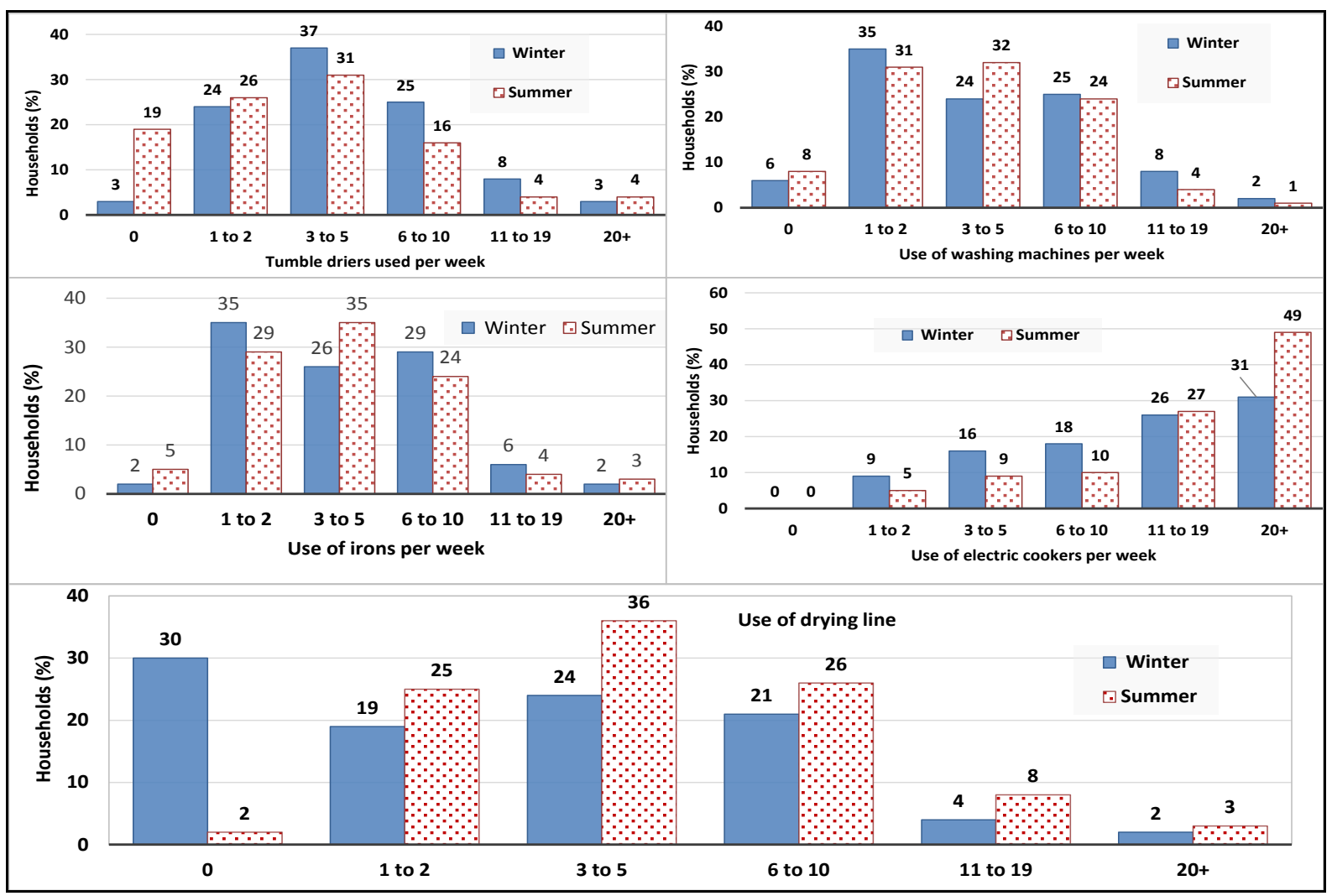

Figure 5: Weekly use of some appliances by households in Libya.

In terms of energy consumption, the main used domestic appliances are washing machines, tumble driers, electric cookers and irons. These appliances could save energy if they have higher energy ratings, shorter or cooler washing cycles or reduced frequency of use. Moreover, the use of drying line instead of tumble driers, in which there is possible benefit from the sun. However, in dusty weather people might avoid using them. 


\subsection{Domestic lighting}

According to a report from Libyan Ministry of Planning, (Global Insights 2012) [57] the power required to run all the appliances for a home inhabited by the same family with area of $450 \mathrm{~m}^{2}$ is about $85 \mathrm{kWh}$ daily $[57,58]$. According to household's survey, it is remarkable that $25 \%$ of the electricity consumed is in lighting. Therefore in order to make a significant reduction in domestic energy consumption in Libya, it is recommended to use energy efficient lighting [59]; this should be coupled with spreading awareness of energy saving lightening and their advantages among the Libyan.

As a consequence of the high prices for economy lighting and the lack of new regulations or tax system to limit the use of traditional lighting, the majority of lighting used by Libyan householders are still traditional light bulbs. Also, there is a need from the government, educational institutions and media to improve the awareness of using more sustainable lighting technologies. The authors have found that $18 \%$ of households use energy saving lighting somewhere within the house. Figure 6 demonstrates the percentage of homes where fluorescent, halogen and traditional light bulbs are used. In Libya traditional bulbs are popular for many reasons. The luminous efficacy of traditional light sources such as incandescent bulbs is about $11-12 \mathrm{~lm} / \mathrm{W}$. In other words, to truly substitute a $40 \mathrm{~W}$ incandescent light bulb, the luminous flux must reach at least $450 \mathrm{~lm} / \mathrm{W}$ [60]. Old people cannot see very well, they need a strong light, but more or less any age still buys them [61]. Many people do not like energy efficient bulbs [68] due to the time required for the bulb to reach full illumination or the quality of light. Furthermore, they are of little advantage in rooms which are used rarely. Halogen bulbs are often used in groups of 3, 4, and 6 or more as spotlights within a room, organised by a single switch. And in spite of the fact they are used in fewer homes than traditional or fluorescent tubes, nevertheless their total number is larger. Halogen bulbs with only $20 \mathrm{~lm} / \mathrm{W}$ are less efficient than fluorescent tubes which can generate up to $90 \mathrm{~lm} / \mathrm{W}$ [62]. Therefore, the usage of fluorescent bulbs is a clear choice from energy consumption point of view [63]. Figure 6 presents data on Libyan households of different types of lightening options, and Figure 7 depicts locations of energy saving light bulbs in Libyan households. 


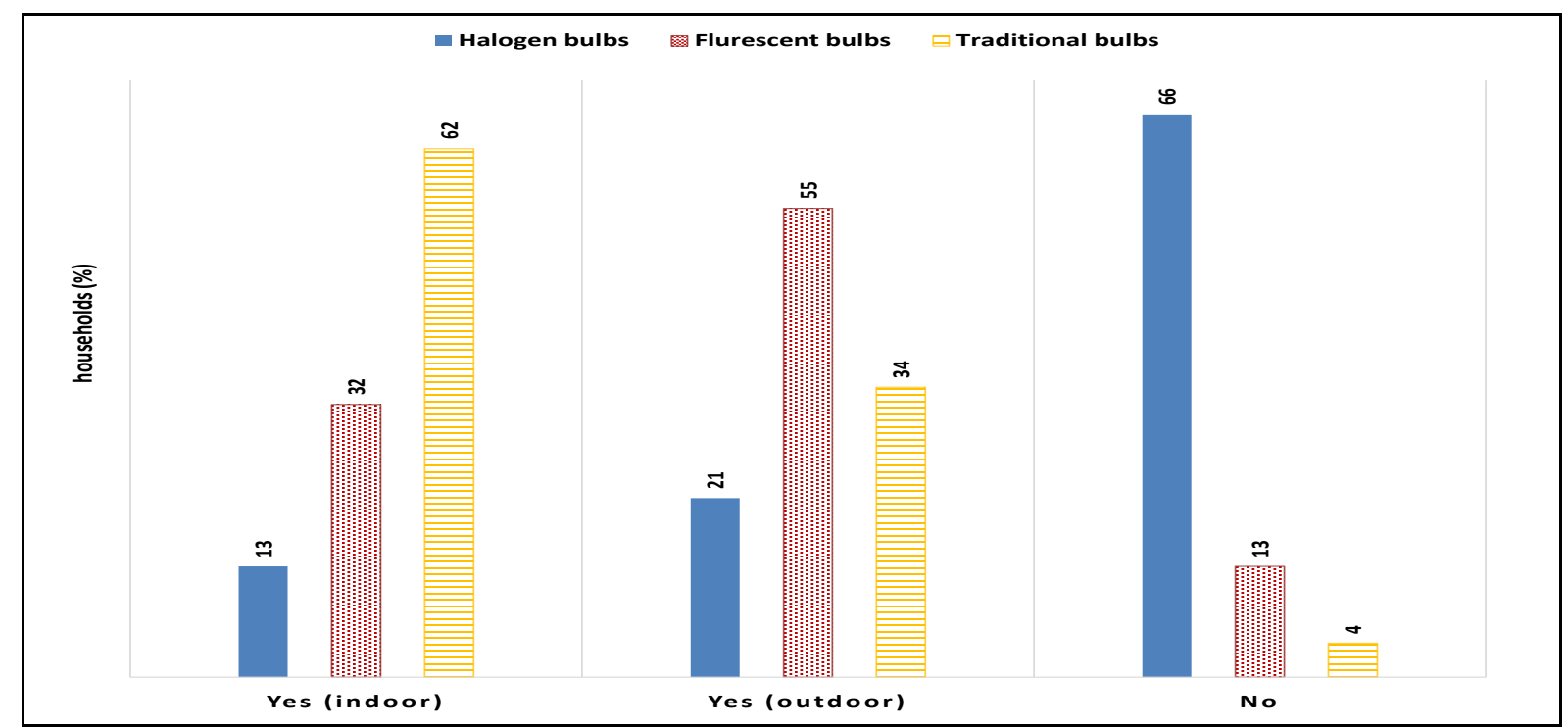

Figure 6: Percentage of homes with fluorescent, halogen and traditional lighting.

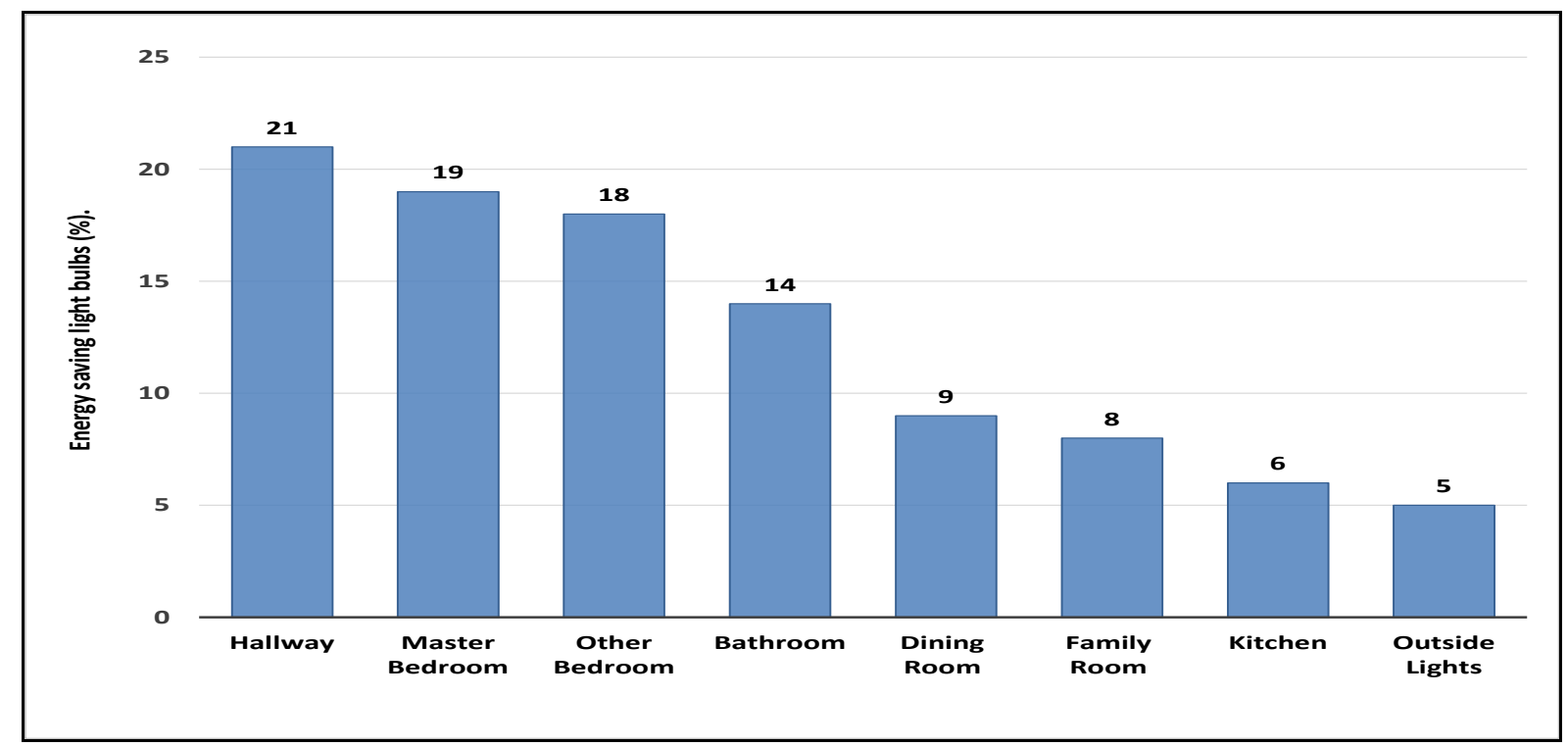

Figure 7: Location of energy saving light bulbs in the Libyan households.

The extent of usage of security lighting differs widely: duration varies from every single day and all night-time, to only when residents are out. Number of light varies from a single light to multiple lights; and rating of bulbs differs from $40 \mathrm{~W}$ to $500 \mathrm{~W}$ lamps. For this reason, it is not possible to measure the amount of electricity used, but observation has revealed that while the amount of electricity consumed is not huge on a single dwelling basis, the use of timers would make a useful decrease in the consumption of energy from the network.

The change to more energy-efficient choices could help in saving energy as well as money. An old-fashioned incandescent bulb (traditional bulbs) (60W, 800 lumens) has an expected 
life of 1,000 hours comparing with fluorescent bulbs (14W, 800 lumens) which has 10,000 hours life and LED light bulbs (16W, 800 lumens) could have an average operating life of 25,000 hours.

In focus on traditional and LED bulbs, it can be noticed that the difference of power between them is $44 \mathrm{~W}$. If the traditional light bulbs (Figure 6) are replaced by LEDs for Libyan domestic households, the energy savings in one year can be calculated based on the number of domestic households of 90,5970 in libya as approximately 170 GWh which is equivalent to 34 million LD (approximately $£ 17$ Million). This is in fact a significant reduction of electricity usage and worth receiving governmental and society efforts in order to make it real.

\subsection{Energy behaviour and energy awareness}

\subsubsection{General awareness of energy issues}

Figure 8 illustrates the awareness of householders of a number of energy-saving measures; the figure depicts, via statistical presentation, that residents are in fact aware of many energysaving measures. These statistics reveal that the Libyan householders are in fact aware to a good extent of energy efficiency measures, however applying these measures seems to be another issue. This presents another challenge to the Libyan government on introducing efficiency measures and promoting these measures in order to achieve energy sufficiency and cut on carbon emissions.

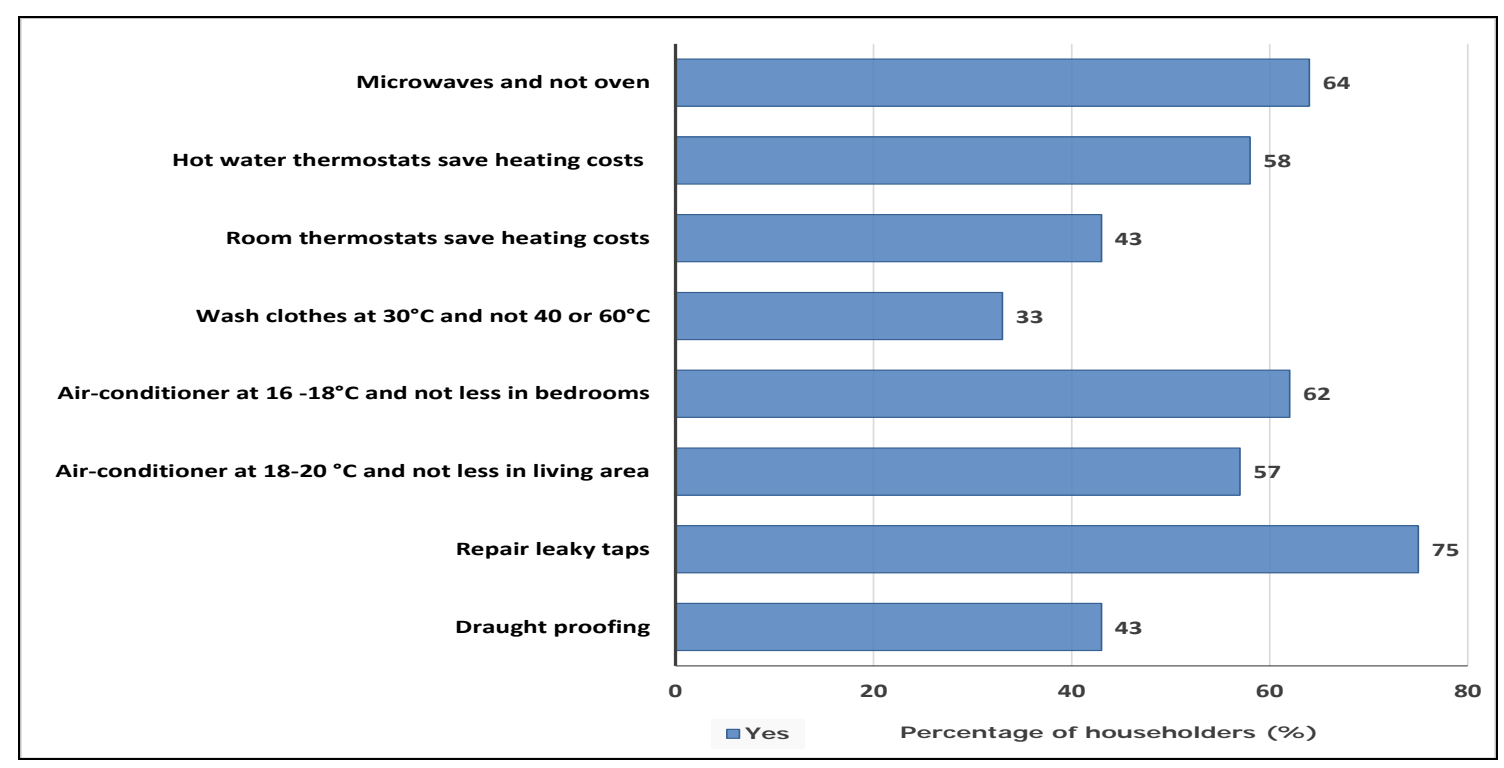

Figure 8: Libyan householders’ general awareness of some energy-saving measures. 


\subsubsection{Views on energy-efficiency measures and associated investment}

Householders were asked for their opinions on a further variety of energy saving measures to evaluate their information and consideration in relation to these specific measures. The results are illustrated in Figure 9.

Figure 9: Householders’ views on general efficiency and energy saving measures.

Figure 9 suggests that majority Libyans are not interested in investing in energy saving measures. The understanding or appreciation of energy-saving schemes is disappointing. One could debate that the financial investment related to the installation of these systems might be the problem. On the other hand, it is unexpected to discover that only $36 \%$ of the respondents considered installing draught proofing since the expenditure associated with it might be less significant. On the matter of using A-rated appliances and energy-saving light bulbs, 63\% and $75 \%$, respectively, would consider positive actions. Clearly, there is a larger appreciation of their benefits.

Figure 10 and Table 7 present the householders views on some aspects of sustainability. Figure 10 illustrates the results of questions ranging from 'strongly disagree' to 'strongly agree' on a number of energy-saving matters: use green products to assist the environment', 'financial incentive would encourage energy saving', 'energy saving is economical', there is a 'moral obligation to save energy', and 'individual's effort has an influence on the environment'. Whilst it seems that the majority believe individual effort will have a positive 
impact on energy saving, there is central tendency towards neutrality of the subject of the other sustainability issues.

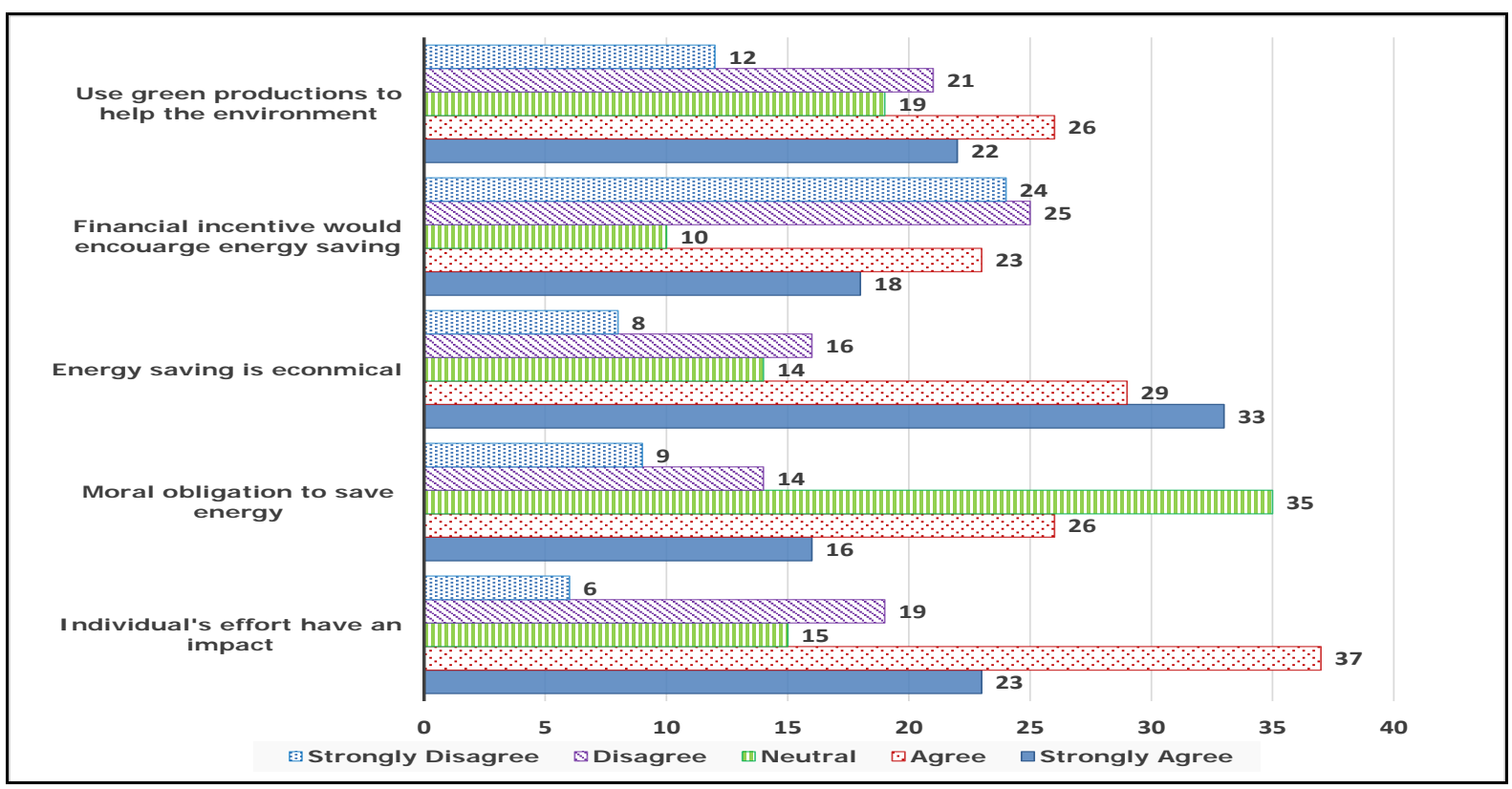

Figure 10: Householders’ views on energy saving issues.

Table 7: Householder's views on energy saving behaviour

\begin{tabular}{|c|c|c|c|c|c|}
\hline Theme & Res & nse & & & \\
\hline $\begin{array}{l}\text { A: never; B: rarely; C: sometimes; D: usually; E: } \\
\text { always. }\end{array}$ & A & B & $\mathrm{C}$ & $\mathrm{D}$ & $\mathrm{E}$ \\
\hline Invest in energy saving devices & 37 & 29 & 19 & 9 & 6 \\
\hline Leave appliances on standby & 9 & 8 & 13 & 38 & 32 \\
\hline TV on whilst doing other things & 5 & 13 & 19 & 41 & 22 \\
\hline Lower thermostat setting (heat) & 42 & 26 & 13 & 11 & 8 \\
\hline Lower thermostat setting (cool) & 35 & 31 & 16 & 12 & 6 \\
\hline Curtains open when heating is on & 13 & 17 & 21 & 23 & 26 \\
\hline Curtains open when cooling is on & 36 & 26 & 18 & 11 & 9 \\
\hline Only heat rooms that are used & 21 & 17 & 12 & 24 & 26 \\
\hline Only cool rooms that are used & 17 & 22 & 11 & 19 & 31 \\
\hline More clothes before heating & 31 & 20 & 9 & 21 & 19 \\
\hline Less clothes before cooling & 23 & 17 & 10 & 23 & 27 \\
\hline Use daylight as much as possible & 16 & 15 & 21 & 27 & 21 \\
\hline Control of lighting level & 22 & 19 & 13 & 22 & 24 \\
\hline Turn lights off & 11 & 15 & 21 & 24 & 29 \\
\hline Use clothes line & 7 & 12 & 19 & 21 & 41 \\
\hline Dryer at full load & 7 & 12 & 8 & 21 & 52 \\
\hline Dishwasher at full load & 6 & 18 & 21 & 24 & 31 \\
\hline Washing machine at full load & 4 & 9 & 21 & 31 & 35 \\
\hline Match dishwasher cycle to load & 12 & 15 & 21 & 24 & 28 \\
\hline Lids on when cooking & 6 & 9 & 16 & 48 & 21 \\
\hline
\end{tabular}




Theme
$\begin{aligned} & \text { A: never; B: rarely; C: sometimes; D: usually; E: } \\
& \text { always. }\end{aligned}$
\begin{tabular}{|l|l|l|l|l|l|l|}
\hline Shower or half-full bath & \multicolumn{1}{c}{ B } & \multicolumn{1}{l}{ C D } & \multicolumn{2}{c}{ E E } \\
\hline Fill kettle only to requirements & 11 & 21 & 19 & 22 & 51 \\
\hline Use cooker not kettle for boiling water & 13 & 22 & 19 & 16 & 36 \\
\hline Use appropriate size cooking pots & 14 & 21 & 14 & 25 & 26 \\
\hline
\end{tabular}

Table 7 demonstrates that only 15\% of residents assume that they will (usually 9\% and always 6\%) invest in energy-saving technologies, and 19\% sometimes; the remaining 66\% (37\% - 29\%) would respectively (never or rarely) invest in energy-saving technologies. The ratio of those who leave appliances on standby to those who do not is about 70:30 respectively. However, this is promising; the aim must be to exclude standby usage, not only for decreasing energy use, but also for health and safety reasons.

In terms of standby, the number of householders leaving their everyday appliances on standby mode is significantly high (70\%). This leads to significant loss of energy and this contributes to energy security problem in Libya. For example, if digital TVs and Satellite Receivers (less than 10 years old) are left on-standby for 8 hours per day, with an average TV numbers of 1.75 per household, the energy wasted in one year will be 10 watts $\times 1.75 \mathrm{TV} \times 8$ hours $\times 365$ days $/ 1000=51,1 \mathrm{kWh}$ per year. Moreover, the total electricity used and cost for Libyan population is $(905,970$ domestic householders $\times 70 \%$ of households who leave their appliances on standby mode) $=634,179 \times 51,1 \mathrm{kWh}=32 \mathrm{GWh}$. This cost about $32 \mathrm{GWh} \times 0.20$ Dirham = 6.5 million LD yearly (approximately $£ 3.25$ million).

Over $17 \%$ would lower thermostat settings of their heating systems and over $18 \%$ would reduce thermostat settings of their cooling systems. $49 \%$ would leave curtains open usually or always when heating is on; and 20\% would leave curtains open usually or always when cooling system is on. Approximately 38\% would (never $21 \%$ or rarely $17 \%$ ) heat only rooms that are used and around 39\% would (never 17\% or rarely 22\%) cool only rooms that are used. With regard to putting on more clothes before switching on the heating, 51\% said they would not.

Over $48 \%$ would use daylight as much as possible and almost the same number of residents would control lights in their homes; more than 53\% believed that they would turn lights off when the room is not in use. 


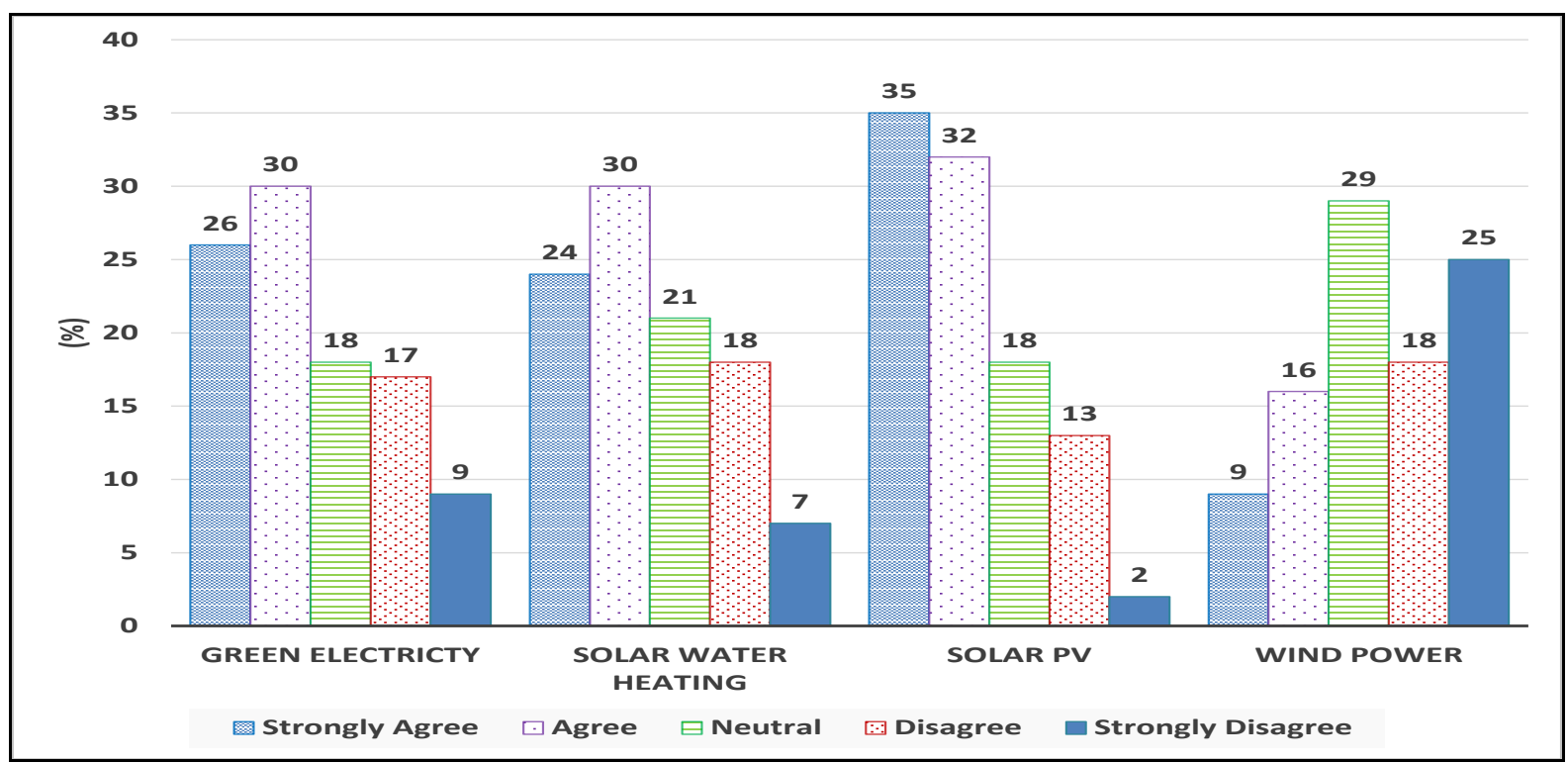

Figure 11: Householder's behaviour on renewable energy resources and CO2 reduction schemes.

Figure 11 presents the attitude in relation to renewable energy resources. It shows that more than $56 \%$ support green electricity, however a significant number of people (18\%) are neutral on the topic, representing possibly a lack of familiarity of what green electricity is. With regard to the installation of solar water heating systems, solar power or wind power systems, Over 54\% either agree (or strongly agree). Those in disagreement in each case are a smaller (less than $4 \%$ ), which is promising.

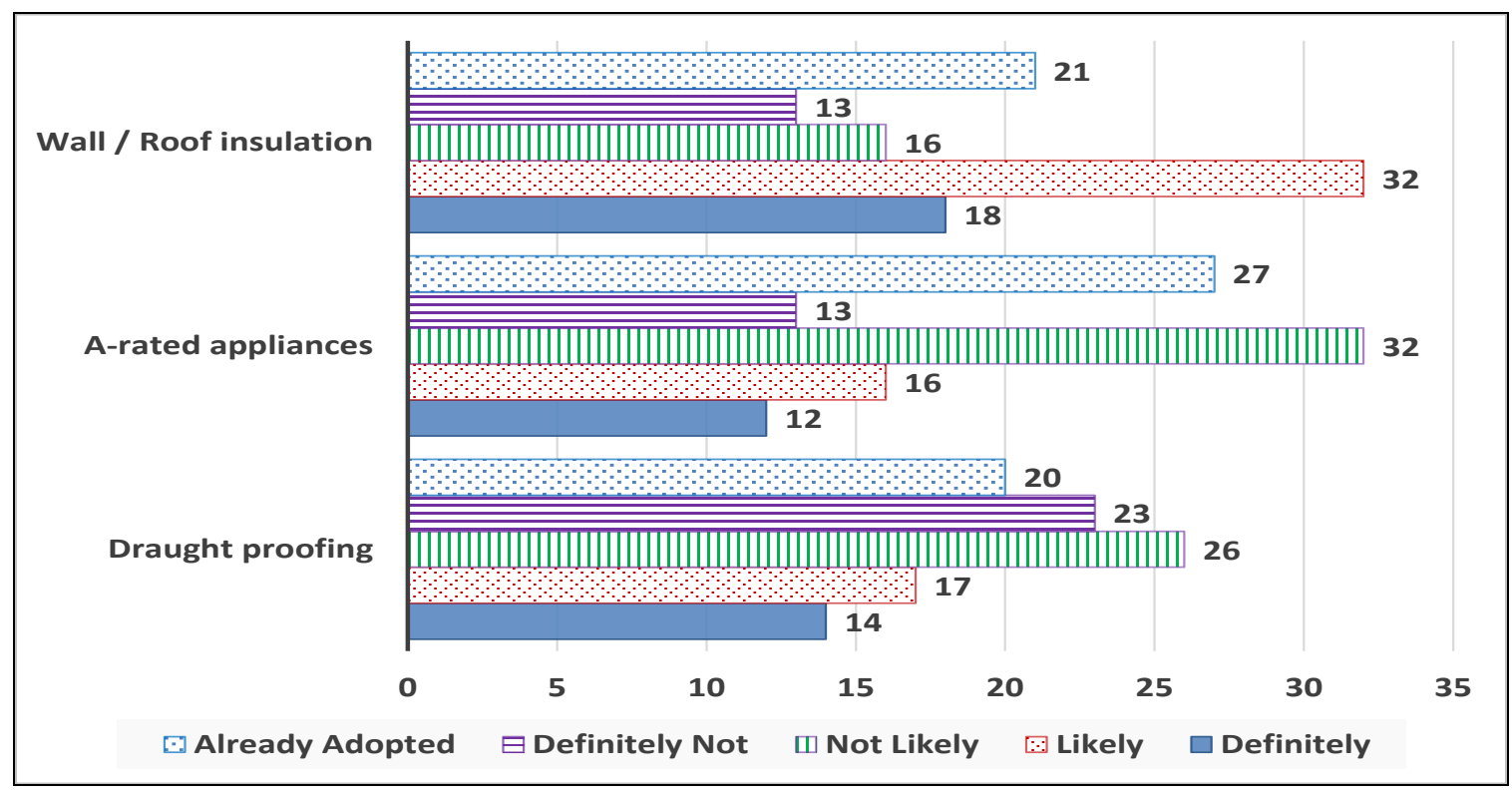

Figure 12: Prospect householder’s possible future investments in energy saving measures.

Figure 12 presents the future plan of the householders in relation to renewable measures. The householders who have answered definitely are 18\%, $12 \%$ and $14 \%$ for wall/roof insulation, 
A-rated appliances and draught proofing respectively. This is a clear indication that most people do not have sustainability measures on their future agenda for energy improvement. From a policy maker's viewpoint, with the aim of accomplish cut of energy waste and decrease in household energy usage, it would be essential to adopt a strategy that includes variety of measures and tools and the delivery of information is just one of them [30]. Table 9 presents householder's views on the best method of obtaining information on energy issues where energy bills come first (56\%) followed by TV and newspapers; This is in line with Mullaly's findings [63], where $73 \%$ believed that utility companies should offer better information concerning the energy consumption by a variety of appliances. A number of researchers have examined the nature of the information required and how best to offer it (e.g. Lutzenhiser, 1993) [47]. This examination has revealed that general energy awareness is good; however residents' implementation of energy- efficiency measures does not match their claim of awareness.

Table 7: Householder's views on the most suitable method of obtaining information on energy issues

\begin{tabular}{|c|l|}
\hline Preferred method of receiving information & $\begin{array}{l}\text { Response } \\
(\%)\end{array}$ \\
\hline Energy bills (monthly or quarterly) & 56 \\
\hline Newspapers & 14 \\
\hline Telephone helpline & 0 \\
\hline Literature & 3 \\
\hline TV programmes & 25 \\
\hline Radio & 2 \\
\hline
\end{tabular}

\subsection{Adjustment in occupant's behaviour}

To measure the importance of the influence of the consumers' behaviour on energy demand, the information from the survey has been compiled based on the average characteristic of the Libyan consumers to present the average behaviour of a Libyan household as shown in Appendix 2. The table presents a typical Libyan household in relation to the appliances and their power. The average energy consumption is about 37,757.88 $\mathrm{kWh}$ per annum. The result for one household can be generalised for the full number of accounts (Households) available at the Libyan General Electricity Company which is 905,970 accounts. Hence the monthly consumption is $905,970 \times 3.147 \mathrm{MW}=2,850,626 \mathrm{MWh}$ (circa $2850 \mathrm{GWh}$ ) per month. At the same time the total actual cost of the same population is 905,970 accounts $\times 1318.516=1,194$ million Libyan dinars per year (circa $£ 597$ million). 
To investigate the relevance of improving the occupants' behaviour, the authors have created an improved scenario as presented in Appendix 3. The authors made some modifications and improvements in the occupants' behaviour as a sustainability measure to include a scenario of possible reduction in the number of appliances, weekly frequency of use and daily hours of use. The calculations have been done for the same average household in Appendix 2 and the improved behaviour energy data is documented in Appendix 3. Appendix 3 shows the real average of the householders' consumption sample and their cost through the year of 2012 which is about 3,146.490 kWh monthly which equals 3.147 MWh.

According to Appendix 3, the average monthly consumption of the householders' sample in 2012 is about $1,494.587 \mathrm{kWh}(1.495 \mathrm{MWh})$. For the full number of accounts available at the Libyan General Electricity Company which is 905,970 accounts the total can be calculated as 1354 GWh per month. At the same time the total cost will be 905,970 households $\times 542.909=$ 492 million Libyan dinars per year (circa £246 million).

Appendix 3 demonstrates the level of savings in electricty for the reduction in number of units and/or the duration of use. The focus has been on immersion heaters, kettles, TV sets and vaccum cleaners. For example, reducing the number of TV ( Plasma, LCD ) from 7 TVs to only 2 , considering that most libyan families are watching television together, should be a simple way to save energy. Reducing the number of vacuum cleaners use from 5 times a week to 2 times a week with the same duration and doing some of the cleaning with other manual systems. Reducing the working hours on computer desktops and laptops from 4 to 2 hours per day. Moreover, switching off the broadband wriless router during sleeping hours that should save significant energy and expenditure of householder. These results are reflected on the libyan volume of production as shown in Tables 8 as well as reducing fund allocations for electricity of the state budget also shows the size of the savings achieved when making some changes in behavior and energy efficient in the home under study.

There has been also a re-arranging in the lighting and the expansion in the use of $40 \mathrm{w}$ halogen from 6 to 14 bulbs and type 60w from 6 to 8 . At the same time, there has been reduction in the usage of old type 100w from 9 to 1 and type $75 \mathrm{w}$ from 4 to 2 keeping the total number of bulbs (the owner unable to buy the economic bulbs).

Table 8 demonstrates the results of the improvement scenario in MWh and the savings for one year in the household's sample. It is clear that significant energy savings can be achieved as a result of simple behavioural changes that affect the number of appliances and the number 
of times used in the home. The simple change in behaviour could save energy per annum equivelenat to a large power station of capcacity of 2 GWh.

Table 8: Summary of improvement in total cost and MWh consumption (per annum).

\begin{tabular}{|c|c|c|}
\hline Houshold's chosen & $\begin{array}{c}\text { MW.h } \\
\text { consumpation }\end{array}$ & $\begin{array}{l}\text { Consumpation } \\
\text { cost } \\
\text { (Libyan- } \\
\text { dinars) }\end{array}$ \\
\hline $\begin{array}{l}\text { Current situation } \\
\text { (More details in Table 4) }\end{array}$ & 37.7 & 1318.516 \\
\hline $\begin{array}{l}\text { Improved sustainable scenario } \\
\text { (More details in Table 5) }\end{array}$ & 17.9 & 542.909 \\
\hline $\begin{array}{l}\text { Saving MW.h and amount per person } \\
\text { (Difference between before and after } \\
\text { scenario) }\end{array}$ & 19.8 & 775.607 \\
\hline $\begin{array}{l}\text { Total accounts (Population) } \\
\text { (In the Libyan General Electricity } \\
\text { Company) }\end{array}$ & \multicolumn{2}{|c|}{905970} \\
\hline $\begin{array}{l}\text { Total saving for the population } \\
\text { of (sample } \times \text { population) }\end{array}$ & 17938206 & 703 million \\
\hline $\begin{array}{l}\text { Real expenses } \\
\text { in Libyan's budget of } 2012\end{array}$ & - & 6,000 million \\
\hline $\begin{array}{l}\text { Expected cost after the improvement } \\
\text { scenario }\end{array}$ & - & 5,297 million \\
\hline Expected money Saving in Libyan's pudget & - & 703 million \\
\hline $\begin{array}{l}\text { Expected annual saving in Libya's } \\
\text { electricity prodction of (sample } \times \\
\text { population) }\end{array}$ & $\begin{array}{c}17938206 \mathrm{MWh} \\
\text { Equivelant to the } \\
\text { power of a } 2 \mathrm{GW} \\
\text { power plant }\end{array}$ & \\
\hline
\end{tabular}

\section{People's behaviour}

The results from the survey have presented some important facts about people's behaviour and expected energy consumption and savings as a result of that. It has been clear from Figure 2 that as soon as there is a decrease or increase in temperature, heating or cooling systems will be switched on; this is as direct result of poor house insulation combined with low energy cost. Tables 4 and 5 indicate the longevity of many of the electrical systems that the Libyan use at home. This is a positive point towards sustainability in general, however, most of the systems might be less efficient in comparison to modern systems and will be consuming more electricity. This is reflected in the fact that the majority of people do not know about the energy performance of their appliances, see Figure 4. Part of the reason could 
be related to the relatively low cost of the energy and its subsidisation; further discussion regarding this will be presented in the next section. It is supervising that people still significantly use their tumble dryers in summer despite the fact of the warm and dry weather, see Figure 5. The main findings, however, in relation to people's behaviour is their lack of knowledge, awareness or interest in relation to general efficiency and energy saving measures, see Figures 9 to 12. In general, the paper has found that a minor change in behaviour could reduce the energy consumption to the equivalence to a about 2GW energy generation plant.

\section{Policy Implication}

GECOL operates 71 power plants distributed across Libya in 14 main power stations (14 Steam, 32 Gas, 15 Combined Cycle and other Resources). However, the company annual reports show that the quantity produced is much more than the electricity paid for by the customers, indicating there are many customers who could be using electricity without metering, in a possible illegal action by some customers. Many regions and major cities in Libya suffer from electricity interruption for long hours although the state has a number of administrative and economic instruments that can be used to stop depletion of public money and to conserve energy such as launching awareness campaigns, privatisation, adoption of the rating agencies used globally, increasing taxes on inefficient imports that would consume a large amounts of energy, adoption of direct and indirect subsidy cuts on locally consumed energy and the adoption of basic policy toward renewable energy technology to reduce the burden on the traditional sources and preserving the environment. This can lead to a competition for the production of energy from other sources, such as wind, sun, waves and others.

It is important for Libya to have a clearer and firmer energy policy that highlights energy security concerns and provides solutions and measures to downsize any energy problems that may face the country. In so doing, the policy needs to focus much enough on widening the awareness among the general public of energy related issues, such as energy cost, domestic appliances rating, awareness of energy saving equipment, tips on how energy can be conserved and consequences of not changing energy consumption behaviour. It is advisable that the Libyan government makes the general public aware of the current energy capacity in Libya and how this may be improved should energy conservation measures be put in place, and how such implementation may benefit the Libyans. Furthermore, in order to overcome any possible sever energy security problem and provide a sustainable energy supply the 
Libyan energy policy needs to provide motivations and supports to investments in energy projects and particularly to renewable energy projects.

\section{Conclusion}

This paper investigates domestic energy use and householders' energy behaviour in Libya. The paper has outlined the expected annual increase of electricity demand in Libya. This expected increase would mean that Libyan has to invest in a new infrastructure that could cost significant amount of money, or households will face programmed power cuts. A survey of 429 households in Libya has provided comprehensive information regarding the energy situation and demand in the domestic market and people's behaviour. It has been found that the government and the local communities should take further steps to educate the Libyans in relation to the benefits of implementing measures to reduce and control energy consumption and carbon emission, and therefore reduce the energy bills for the households and ease the increased demand burden from the government, hence tackle energy security concerns in good time. The study also has found that utilising more efficient appliances and lighting combined with improved behaviour could significantly reduce the energy demands in Libya that is almost equivalent to a large power station of $2 \mathrm{GW}$.

Being this study almost the first to be conducted on the effects of energy consuming behaviour on the overall Libyan energy position the results of this study should be of particular importance to a number of stakeholders. First category of those stakeholders are the Libyan general public who should be aware of the effects of energy consumption behaviour on energy issues and who have the right for sustained and affordable energy supply. Energy analysis, energy planners, policy makers, current and potential investors in the Libyan energy sector should also be able to make benefits of this study in one way or another. Libya energy consumption is a typical example of the consumption of many counties within the MENA region. For sustainable energy production and exporting to Europe to be possible, it is important to address the local consumption and its increase in order for this vision to become a reality. The reduction in local consumption could provide energy and carbon savings and at the same time additional energy, including energy from sustainable resources, could be exported to Europe benefiting both sides of the Mediterranean. Whilst this study has tackled the effects of energy consuming behaviour on the overall energy consumption and demand in Libya and offered a scenario of reducing energy consumption it did not touch on the effects 
of different policy measures on changing the consuming behaviour of Libyan households. This topic is worth researching and this must be our next research study.

\section{Acknowledgements}

The authors would like to acknowledge the support of Mr. Mohamed Ayad El-Barghthi, Mrs. Fatma Suliman Salem, Mrs. Salha El-wafi El-abar and Mr. Issa Saleh El-Barghathi for their assistance, supporting and significant contribution in conducting the survey. 


\section{References}

[1] T. Franz, "Project manager for the TRANS-CSP and the associated AQUA-CSP and MED-CSP report.,” 2011.

[2] A. M. A. Mohamed, A. Al-habaibeh, and A. Hafez, "the Significance of Utilising Renewable Energy Options Into the Libyan Energy Mix,” Energy Res. J., vol. 4, no. 1, pp. 15-23, Jan. 2013.

[3] A. M. A. Mohamed, A. Al-Habaibeh, and H. Abdo, "An investigation into the current utilisation and prospective of renewable energy resources and technologies in Libya," Renew. Energy, vol. 50, pp. 732-740, Feb. 2013.

[4] J. Wright, “Libya: Country Analysis Briefs,” 250 Park Avenue, Suite 2000, New York, NY 10017, 2012.

[5] GECOL, “General Electricity Company of Libya Report.,” Libya, 2013.

[6] A. Brandon, G., Lewis, "Reducing household energy consumption : a qualitative and quantitative field study.,” J. Environ. Psychol., vol. 19, pp. 75-85, 1999.

[7] L. Schipper, A. Ketoff, and S. Meyers, "International residential energy demand use data: analysis of historical and present day structure and dynamics.," Energy, vol. 7, no. 2, pp. 205-212, 1982.

[8] R. Missaoui and A. Mourtada, "Instruments and Financial Mechanisms of energy efficiency measures in building sector," World Energy Counc. ADEME, no. August, 2010.

[9] Y. G. Yohanis, “Domestic energy use and householders’ energy behaviour,” Energy Policy, vol. 41, pp. 654-665, Feb. 2012.

[10] G. Y. Y. Koen Steemers, "Behavioural, physical and socio-economic factors in household cooling energy consumption,” Appl. Energy- Elsevier Sci. Ltd, vol. 88, no. 6, pp. 2191-2200, 2011.

[11] G. Yohanis and B. Norton, "Life-cycle operational and embodied energy for a generic single-storey office building in the UK.,” Energy, vol. 27, no. 1, pp. 77-92, 2002.

[12] K. B. P. Shanks, S. N. G. Lo., and B. Norton, "Energy efficient buildings’ envelope technologies for social housing refurbishment.,” J. Hous. Built Environ., vol. 21, no. 2, pp. 191-202, 2006.

[13] M. Wood, G., Newborough, "Dynamic energy-consumption indicators for domestic appliances: environment, behaviour and design.,” Energy Build., vol. 10, pp. 73-79, 2003.

[14] GECOL, “General Electricity Company of Libya Report.,” Libya, 2011. 
[15] CTNI, "Vision Study for Northern Ireland, the Carbon Trust, UK,." http://www.thecarbontrust.co.uk/carbontrust/, 2005.

[16] S. D. Mansouri, I., Newborough, M., Probert, "Energy consumption in UK households: impact of domestic electrical appliances.,” Appl. Energy, vol. 54, no. 3, pp. 211-285, 1996.

[17] P. A. Nilssen, "Household energy use and the environment-a conflicting issue.," Appl. Energy, vol. 76, pp. 189-196, 2003.

[18] J. A. Andrade, “The uses of energy in the domestic sector,” Energy Build., vol. 33, pp. 525-529, 2001.

[19] BRANZ, "Household Energy End-use Project, Annual Reports and Study Reports 1995-2004,” 2005.

[20] M. T. Leach, N.L., Latta, R.B., Laurence, "Collecting energy-related behaviour information in the real world.," Proc. ACEEE Summer Study Energy Efficiency Build., vol. 8, pp. 197-205, 2000.

[21] Y. G. Yohanis, . J. D. M., W. . Alan, and N. Brian, "Real-life energy use in the UK: How occupancy and dwelling characteristics affect domestic electricity use,” Energy Build., vol. 40, no. 6, pp. 1053-1059, 2008.

[22] C. Palmborg, "Social habits and energy consumption in single-family homes.," Energy, vol. 11, no. 7, pp. 643-650, 1986.

[23] J. C. Lam, "Climatic and economic influences on residential electricity consumption," Energy Convers. Manag., vol. 39, no. 7, pp. 623-629, 1998.

[24] R. Wilhite, H.L., Wilk, “A method for self-recording household energy-use behavior.,” Energy Build., vol. 10, pp. 73-79, 1987.

[25] A. W. H. Lee, "Verification of electrical energy savings for lighting retrofits using short- and long-term monitoring.,” Energy Convers. Manag., vol. 41, pp. 1999-2008, 2000 .

[26] C. Goldman, "Measured energy savings from residential retrofits: updated results from the BECA-B project.,” Energy Build., vol. 8, pp. 137-155, 1985.

[27] L. Seligman, C., Darley, J.M., Becker, “. Behavioural approach to residential energy conservation.”, Energy Build., vol. 1, pp. 325-337, 1977.

[28] G. Poortinga, W., Steg, L., Vlek, C., Wiersma, “. Household preferences for energysaving measures: a conjoint analysis.,” J. Econ. Psychol., vol. 24, no. 1, pp. 49-64, 2003.

[29] L. Abrahamse, W., Steg, "How do socio-demographic and psychological factors relate to households' direct and indirect energy use and savings?,” J. Econ. Psychol., vol. 30, no. 5, pp. 711-720, 2009. 
[30] J. M. Carrico, A.R., Vandenbergh, M.P., Stern, P.C., Gardner, G.T., Dietz, T., Gilligan, "Energy and climate change: key lessons for implementing the behavioral wedge.," $J$. Energy Environ. Law, vol. 2, no. 61, pp. 61-67, 2011.

[31] H. Owens, J., Wilhite, "Household energy behaviour in Nordic countries-an unrealized energy saving potential,” Energy, vol. 13, no. 12, pp. 853-859, 1988.

[32] A. Naief, R. Yacine, and K. Alan, "Domestic energy consumption patterns in a hot and humid climate: A multiple-case study analysis,” Appl. Energy- Elsevier Sci. Ltd, vol. 114, pp. 353-365, 2014.

[33] R. Firth, S., Lomas, K., Wright, A., Wall, "Identifying trends in the use of domestic appliances from household electricity consumption measurements.," Energy Build., vol. 40, no. 5, pp. 926-936, 2008.

[34] G. Hitchcock, "An integrated framework for energy use and behaviour in the domestic sector.,” Energy Build., vol. 20, no. 2, pp. 151-157, 1993.

[35] T. Druckman, A., Jackson, "Household energy consumption in the UK: a highly geographically and socio-economically disaggregated model.,” Energy Policy, vol. 36, no. 8, pp. 3177-3192, 2008.

[36] H. C. Kerkhof, A.C., Benders, R.M.J., Moll, "Determinants of variation in household CO2 emissions between and within countries.," Energy Policy, vol. 37, no. 4, pp. 1509-1517, 2009.

[37] S. Roberts, “Demographics, energy and our homes.,” Energy Policy, vol. 36, no. 12, pp. 4630-4632, 2008.

[38] T. Wall, R., Crosbie, "Potential for reducing electricity demand for lighting in households: an exploratory socio-technical study.,” Energy Policy, vol. 37, no. 3, pp. 1021-1031, 2009.

[39] NIE, "Saving energy at home. Northern Ireland Electricity.” 2011.

[40] Action Renewable, “Action Renewable.” 2011.

[41] L. Lutzenhiser, "Social and behavioral aspects of energy use.," Annu. Rev. Energy Environ., vol. 18, pp. 247-289, 1993.

[42] T. Dietz, "Narrowing the US energy efficiency gap.," Proc. Natl. Acad. Sci. U. S. A., vol. 107, no. 37, pp. 16007-16008, 2010.

[43] R. N. Jaffe, A.B., Stavins, “The energy efficiency gap: What does it mean?," Energy Policy, vol. 22, no. 10, pp. 804-810, 1994.

[44] K. Gillingham, K., Newell, R.G., Palmer, "Energy efficiency economics and policy.," 2009. 
[45] NIHE, "NorthernIrelandHouseConditionSurvey, NorthernIrelandHousing Executive,” Belfast, UK, 2001.

[46] N. Andreas, B. Cecilia, T. Liane, D. Anderssonc., K. Anderssona., and M. Pär, "Effects of continuous feedback on households' electricity consumption: Potentials and barriers,” Appl. Energy- Elsevier Sci. Ltd, vol. 122, no. 1, pp. 17-23, 2014.

[47] D. P. J. R.A.R. Kilpatrick, , P.F.G. Banfill, "Methodology for characterising domestic electrical demand by usage categories,” Appl. Energy- Elsevier Sci. Ltd, vol. 88, no. 3, pp. 612-621, 2011.

[48] R. Fact, S. From, T. H. E. World, D. Indicators, M. East, and N. Africa, "Middle East and North Africa," 2009.

[49] S. Africa and I. States, "Energy Subsidies in Middle East and North North Africa: Regional fact sheet from the world development indicators 2009,” pp. 1-4, 2013.

[50] M. G. ; B. N. ; A. M. Almathnani, "UTES potential for space heating and cooling in Libya," in Thermal energy storage : 2006 EcoStock ; [10th International Conference on Thermal Energy Storage] ; May 31 - June 2, 2006, the Richard Stockton College of New Jersey ; proceedings, 2006, p. 7.

[51] Z. Mohamed, "CO2 Emission Factor for the electricity generation system in Libya.," in Proceedings of the Libyan International Conference on Electrical and Electronic Engineering., 2010, pp. 23-26.

[52] O. Waniss and E. Karlberg, The Libyan Economy: Economic Diversification and International Repositioning. Springer - Verlag Berlin Heidelberg 2007, 2007.

[53] E.-A. Khalil, M. Mohamed, E.-O. Belkasem, S. Salah, and S. Osman, "Demand Side Management in Libya - A Case Study of the General Electric Company of Libya: Transmission System Operation and Control Department,” Tripoli- Libya, 2009.

[54] F. Affairs, "Provision of Technical Support / Services for an Economical , Technological and Environmental Impact Assessment of National Regulations and Incentives for Renewable Energy and Energy Efficiency Country Report Libya December 2009 , revised April 2010,” The Ministry of Foreign Affairs of Denmark, 2010.

[55] B. CropSeience, “LIBYA - WEATHER AVERAGES,” Weatherbase, 2014. [Online]. Available: http://www.weatherbase.com/weather/city.php3?c=LY. [Accessed: 30-Oct2014].

[56] C. Mullaly, "Home energy use behaviour: a necessary component of successful local government home energy conservation programs.," Energy Policy, vol. 26, no. 14, pp. 1041-1052, 1998.

[57] IMF, “Global Insights 2012: Libyan Ministry of Planning Report 2012,” 2012. 
[58] A.-H. Fatema and A. Huda, "Electrification of builings using solar energy in Libya.," in Solar Energy Sector, Regulation and Policies., 2012.

[59] DTI, "Energy Consumption in the UK. Department of Trade and and Industry, the Stationary Office, United Kingdom.” 2003.

[60] LEDinside, “LED Light Bulbs Evaluation (40 Incandescent Light Bulbs)- Luminous Flux.," company Web, 2011. [Online]. Available:

http://www.ledinside.com/pricequotes/2011/7/led_bulb_lm_201107. [Accessed: 11Nov-2013].

[61] N. BBC, “The 60W bulb: A luminary love affairNo Title,” BBC magazine, 2013. [Online]. Available: http://www.bbc.co.uk/news/magazine-14715301. [Accessed: 11Nov-2013].

[62] Labcraft, “Labcaft Design Lighting, viewed on 22 July 2011,” 2011. [Online]. Available: http://www.labcraft.co.uk/products/market_selector_leisure.php. [Accessed: 08-Nov-2013].

[63] B. Yohanis, Y.G., Mondol, J.D., Wright, A., Norton, "Household Energy Research Project.," 2005.

[64] CSE, "What uses watt ? How much electricity am I using ? Tips for lower energy bills," 2014. 


\section{Appendices}

Appendix 1: Percentage of households with particular appliances.

\begin{tabular}{|l|c|c|c|c|c|}
\hline \multicolumn{1}{|c|}{ Appliance } & $\begin{array}{c}\text { Current } \\
\text { Year of } \\
\text { the survey } \\
(2013)\end{array}$ & $\%$ & $\begin{array}{c}\text { Previous } \\
\text { five years } \\
(2008-2012)\end{array}$ & $\%$ & Difference \\
\hline Washing machines & 330 & $77 \%$ & 290 & $68 \%$ & $9 \%$ \\
\hline Fridge-freezers & 250 & $58 \%$ & 115 & $27 \%$ & $31 \%$ \\
\hline Microwaves & 30 & $7 \%$ & 30 & $7 \%$ & 0 \\
\hline TV sets & 750 & $175 \%$ & 605 & $141 \%$ & $34 \%$ \\
\hline Iron & 320 & $75 \%$ & 298 & $69 \%$ & $6 \%$ \\
\hline Stereo & 92 & $21 \%$ & 152 & $35 \%$ & $-14 \%$ \\
\hline Computer & 362 & $84 \%$ & 95 & $22 \%$ & $62 \%$ \\
\hline Tumble dryers & 78 & $18 \%$ & 24 & $6 \%$ & $12 \%$ \\
\hline Dishwashers & 201 & $47 \%$ & 52 & $12 \%$ & $35 \%$ \\
\hline Electric Cooker & 163 & $38 \%$ & 32 & $7 \%$ & $31 \%$ \\
\hline Electric Oven & 326 & $76 \%$ & 256 & $60 \%$ & $16 \%$ \\
\hline Electric Kettle & 180 & $42 \%$ & 36 & $8 \%$ & $34 \%$ \\
\hline DVD & 110 & $26 \%$ & 56 & $13 \%$ & $13 \%$ \\
\hline Refrigerators & 420 & $98 \%$ & 416 & $97 \%$ & $1 \%$ \\
\hline Video players & 91 & $21 \%$ & 56 & $13 \%$ & $8 \%$ \\
\hline Gas Cooker & 389 & $91 \%$ & 415 & $97 \%$ & $-6 \%$ \\
\hline Gas Oven & 250 & $58 \%$ & 302 & $70 \%$ & $-12 \%$ \\
\hline Microwave Oven & 60 & $14 \%$ & 0 & 0 & $14 \%$ \\
\hline Video Games & 122 & $28 \%$ & 52 & $12 \%$ & $16 \%$ \\
\hline Immersion heater & 907 & $211 \%$ & 580 & $135 \%$ & $76 \%$ \\
\hline
\end{tabular}

$\%=$ Current numbers / 429 sample size $* 100$. 
Appendix 2: Estimated average Energy (kWh) and cost (LD) to run appliances for one house.

\begin{tabular}{|c|c|c|c|c|c|c|c|c|c|c|}
\hline \multicolumn{11}{|c|}{ Householders' frequency of use (kWh and cost) } \\
\hline \multirow{2}{*}{ Appliance } & \multirow{2}{*}{ Rating } & \multirow{2}{*}{\begin{tabular}{|l} 
Number \\
of \\
Applianc \\
es
\end{tabular}} & \multirow{2}{*}{$\begin{array}{l}\text { Frequency } \\
\text { of use per } \\
\text { week }\end{array}$} & \multirow{2}{*}{$\begin{array}{l}\text { Hours } \\
\text { Used } \\
\text { Per day }\end{array}$} & \multicolumn{4}{|c|}{ Total kWh used* } & \multicolumn{2}{|c|}{ Total cost (LD) } \\
\hline & & & & & Daily & weekly & monthly & yearly & monthly & yearly \\
\hline Immersion heater & $3000 \mathrm{~W}$ & 3 & 7 & 3 & 27.00 & 189.0 & 810 & 9720 & 16.200 & 428.000 \\
\hline Washing machine & $\begin{array}{l}1200- \\
3000 \mathrm{~W}\end{array}$ & 1 & 3.5 & 1.3 & 2.86 & 10.0 & 43 & 515 & 0.858 & 10.296 \\
\hline Hairdryer & $1000 \mathrm{~W}$ & 1 & 3 & 0.3 & 0.30 & 0.9 & 4 & 46 & 0.077 & 0.926 \\
\hline Iron & $\begin{array}{l}1000- \\
1800 \mathrm{~W}\end{array}$ & 1 & 4 & 0.3 & 0.42 & 1.7 & 7 & 86 & 0.144 & 1.728 \\
\hline Electric oven & $\begin{array}{l}2000- \\
2200 \mathrm{~W}\end{array}$ & 1 & 4 & 1 & 2.10 & 8.4 & 36 & 432 & 0.720 & 8.640 \\
\hline Tumble dryer & $\begin{array}{l}2000- \\
4000 \mathrm{~W}\end{array}$ & 1 & 3.5 & 2 & 6.00 & 21.0 & 90 & 1080 & 1.800 & 22.400 \\
\hline Kettle & $\begin{array}{l}2200- \\
3000 \mathrm{~W}\end{array}$ & 1 & 14 & 0.2 & 0.52 & 7.3 & 31 & 374 & 0.624 & 7.488 \\
\hline $\begin{array}{l}\text { Air-conditioning Room in } \\
\text { summer and spring }\end{array}$ & $1000 \mathrm{~W}$ & 3 & 7 & 6 & 18.00 & 126.0 & 540 & 6480 & 10.800 & 266.000 \\
\hline $\begin{array}{l}\text { Air-conditioner Room in } \\
\text { winter and autumn }\end{array}$ & $1000 \mathrm{~W}$ & 3 & 7 & 5 & 15.00 & 105.0 & 450 & 5400 & 9.000 & 212.000 \\
\hline Grill/hob & $\begin{array}{l}1000- \\
2000 \mathrm{w}\end{array}$ & 1 & 2 & 1 & 1.50 & 3.0 & 13 & 154 & 0.257 & 3.086 \\
\hline Microwave and oven & $\begin{array}{l}700- \\
1100 \mathrm{w}\end{array}$ & 1 & 5 & 2 & 1.80 & 9.0 & 39 & 463 & 0.771 & 9.257 \\
\hline Vacuum Cleaner & $\begin{array}{l}500- \\
1200 \mathrm{~W}\end{array}$ & 2 & 5 & 2 & 4.40 & 22.0 & 94 & 1131 & 1.886 & 23.943 \\
\hline Plasma TV & $208-$ & 3 & 7 & 7 & 9.09 & 63.7 & 273 & 3273 & 5.456 & 105.674 \\
\hline
\end{tabular}




\begin{tabular}{|c|c|c|c|c|c|c|c|c|c|c|}
\hline \multicolumn{11}{|c|}{ Householders' frequency of use (kWh and cost) } \\
\hline \multirow{2}{*}{ Appliance } & \multirow{2}{*}{ Rating } & \multirow{2}{*}{$\begin{array}{l}\text { Number } \\
\text { of } \\
\text { Applianc } \\
\text { es }\end{array}$} & \multirow{2}{*}{$\begin{array}{l}\text { Frequency } \\
\text { of use per } \\
\text { week }\end{array}$} & \multirow{2}{*}{$\begin{array}{l}\text { Hours } \\
\text { Used } \\
\text { Per day }\end{array}$} & \multicolumn{4}{|c|}{ Total kWh used* } & \multicolumn{2}{|c|}{ Total cost (LD) } \\
\hline & & & & & Daily & weekly & monthly & yearly & monthly & yearly \\
\hline & $450 \mathrm{~W}$ & & & & & & & & & \\
\hline LCD TV & $\begin{array}{l}125- \\
200 \mathrm{~W}\end{array}$ & 4 & 7 & 7 & 6.30 & 44.1 & 189 & 2268 & 3.780 & 62.000 \\
\hline Freezer & $150 \mathrm{~W}$ & 1 & 7 & 5 & 0.75 & 5.3 & 23 & 270 & 0.450 & 5.400 \\
\hline Fridge & $\begin{array}{l}40- \\
120 \mathrm{~W}\end{array}$ & 1 & 7 & 5 & 0.50 & 3.5 & 15 & 180 & 0.300 & 3.600 \\
\hline Video, DVD OR CD & $100 \mathrm{~W}$ & 3 & 7 & 3 & 0.90 & 6.3 & 27 & 324 & 0.540 & 6.480 \\
\hline Desktop computer & $\begin{array}{l}80- \\
150 \mathrm{~W}\end{array}$ & 1 & 7 & 4 & 0.62 & 4.3 & 19 & 223 & 0.372 & 4.464 \\
\hline Laptop & $20-50 \mathrm{~W}$ & 3 & 7 & 3 & 0.41 & 2.8 & 12 & 146 & 0.243 & 2.916 \\
\hline Broadband router & $10 \mathrm{~W}$ & 1 & 7 & 24 & 0.24 & 1.7 & 7 & 86 & 0.144 & 1.728 \\
\hline Deep fryer & $1200 \mathrm{~W}$ & 1 & 3 & 1 & 1.20 & 3.6 & 15 & 185 & 0.309 & 3.703 \\
\hline Toaster & $\begin{array}{l}800- \\
1500 \mathrm{~W}\end{array}$ & 1 & 7 & 0.3 & 0.47 & 3.3 & 14 & 167 & 0.279 & 3.348 \\
\hline Window fan & $200 \mathrm{~W}$ & 4 & 7 & 6 & 4.80 & 33.6 & 144 & 1728 & 2.880 & 62.000 \\
\hline Lights & $\begin{array}{l}100 w \\
\text { Incan }\end{array}$ & 9 & 7 & 4 & 3.60 & 25.2 & 108 & 1296 & 2.160 & 28.880 \\
\hline Lights & $\begin{array}{l}75 w \\
\text { Incan }\end{array}$ & 4 & 7 & 6 & 1.80 & 12.6 & 54 & 648 & 1.080 & 12.960 \\
\hline Lights & $\begin{array}{l}60 \mathrm{w} \\
\text { Incan }\end{array}$ & 6 & 7 & 3 & 1.08 & 7.6 & 32 & 389 & 0.648 & 7.776 \\
\hline Lights & $\begin{array}{l}40 \mathrm{~W} \\
\text { Halogen }\end{array}$ & 6 & 7 & 8 & 1.92 & 13.4 & 58 & 691 & 1.152 & 13.824 \\
\hline & & & & & 113.57 & 734.181 & 3146.49 & 37757.88 & 62.930 & 1318.516 \\
\hline
\end{tabular}


Incan: incandescent lamps (traditional old bulbs).

Source: Appliance's rating is Centre for Sustainable Energy [64]. Remaining data authors' own based on survey.

* Total kWh used: (Daily= Rating $\times$ Hours used per day $\div 1000 \times$ per number of Appliance)

(Weekly $=$ Rating $\times$ Hours used Per day $\div 1000 \times$ Per number of Appliance $\times$ Number of used weekly )

$\{$ (Monthly= Rating $\times$ Hours used Per day $\div 1000 \times$ Per number of Appliance $\times(30$ days $\div 7$ days $)$ )

$\{($ Yearly= Rating $\times$ Hours used Per day $\div 1000 \times$ Per number of Appliance $\times(12$ months $))$

Total cost used: account regarding to a company slaps table shows above. 
Appendix 3: Improved average energy consumption and cost for one household.

\begin{tabular}{|c|c|c|c|c|c|c|c|c|c|c|}
\hline \multicolumn{11}{|c|}{ Householders' frequency of use (kWh and cost) } \\
\hline \multirow[t]{2}{*}{ Appliance } & \multirow[t]{2}{*}{ Rating } & \multirow{2}{*}{$\begin{array}{l}\text { Number of } \\
\text { Appliances }\end{array}$} & \multirow{2}{*}{$\begin{array}{l}\text { Frequency } \\
\text { of use per } \\
\text { week }\end{array}$} & \multirow{2}{*}{\begin{tabular}{|l} 
Hours \\
Used \\
Per day
\end{tabular}} & \multicolumn{4}{|c|}{ Total kWh used } & \multicolumn{2}{|c|}{ Total cost used } \\
\hline & & & & & daily & weekly & monthly & yearly & monthly & yearly \\
\hline Immersion heater & $3000 \mathrm{~W}$ & 2 & 7 & 3 & 18.00 & 126.0 & 540 & 6480 & 10.800 & 266.000 \\
\hline Washing machine & $\begin{array}{l}1200- \\
3000 \mathrm{~W}\end{array}$ & 1 & 2 & 1.3 & 2.86 & 5.7 & 25 & 294 & 0.490 & 5.883 \\
\hline Hairdryer & $1000 \mathrm{~W}$ & 1 & 2 & 0.3 & 0.30 & 0.6 & 3 & 31 & 0.051 & 0.617 \\
\hline Iron & $\begin{array}{l}1000- \\
1800 \mathrm{~W}\end{array}$ & 1 & 2 & 0.3 & 0.42 & 0.8 & 4 & 43 & 0.072 & 0.864 \\
\hline Electric oven & $\begin{array}{l}2000- \\
2200 \mathrm{~W}\end{array}$ & 1 & 3 & 1 & 2.10 & 6.3 & 27 & 324 & 0.540 & 6.480 \\
\hline Tumble dryer & $\begin{array}{l}2000- \\
4000 \mathrm{~W}\end{array}$ & 1 & 2 & 2 & 6.00 & 12.0 & 51 & 617 & 1.029 & 12.343 \\
\hline Kettle & $\begin{array}{l}2200- \\
3000 \mathrm{~W}\end{array}$ & 1 & 7 & 0.2 & 0.52 & 3.6 & 16 & 187 & 0.312 & 3.744 \\
\hline $\begin{array}{l}\text { Air-conditioner Room } \\
\text { in summer and spring }\end{array}$ & $1000 \mathrm{~W}$ & 1 & 7 & 6 & 6.00 & 42.0 & 180 & 2160 & 3.600 & 62.000 \\
\hline $\begin{array}{l}\text { Air-conditioning Room } \\
\text { in winter and autumn }\end{array}$ & $1000 \mathrm{~W}$ & 1 & 7 & 5 & 5.00 & 35.0 & 150 & 1800 & 3.000 & 62.000 \\
\hline Grill/hob & $\begin{array}{l}1000- \\
2000 \mathrm{w}\end{array}$ & 1 & 2 & 1 & 1.50 & 3.0 & 13 & 154 & 0.257 & 3.086 \\
\hline Microwave and oven & $\begin{array}{l}700- \\
1100 w\end{array}$ & 1 & 3 & 2 & 1.80 & 5.4 & 23 & 278 & 0.463 & 5.554 \\
\hline Vacuum Cleaner & $\begin{array}{l}500- \\
1200 \mathrm{~W} \\
\end{array}$ & 1 & 2 & 2 & 2.20 & 4.4 & 19 & 226 & 0.377 & 4.526 \\
\hline Plasma TV & $\begin{array}{l}208- \\
450 \mathrm{~W}\end{array}$ & 1 & 7 & 7 & 3.03 & 21.2 & 91 & 1091 & 1.819 & 22.735 \\
\hline LCD TV & $\begin{array}{l}125- \\
200 \mathrm{~W}\end{array}$ & 1 & 7 & 7 & 1.58 & 11.0 & 47 & 567 & 0.945 & 11.340 \\
\hline
\end{tabular}




\begin{tabular}{|c|c|c|c|c|c|c|c|c|c|c|}
\hline \multicolumn{11}{|c|}{ Householders' frequency of use (kWh and cost) } \\
\hline \multirow[t]{2}{*}{ Appliance } & \multirow[t]{2}{*}{ Rating } & \multirow{2}{*}{$\begin{array}{l}\text { Number of } \\
\text { Appliances }\end{array}$} & \multirow{2}{*}{$\begin{array}{l}\text { Frequency } \\
\text { of use per } \\
\text { week }\end{array}$} & \multirow{2}{*}{$\begin{array}{l}\text { Hours } \\
\text { Used } \\
\text { Per day }\end{array}$} & \multicolumn{4}{|c|}{ Total kWh used } & \multicolumn{2}{|c|}{ Total cost used } \\
\hline & & & & & daily & weekly & monthly & yearly & monthly & yearly \\
\hline Freezer & $150 \mathrm{~W}$ & 1 & 7 & 5 & 0.75 & 5.3 & 23 & 270 & 0.450 & 5.400 \\
\hline Fridge & $\begin{array}{l}40- \\
120 \mathrm{~W}\end{array}$ & 1 & 7 & 5 & 0.50 & 3.5 & 15 & 180 & 0.300 & 3.600 \\
\hline Video, DVD OR CD & $100 \mathrm{~W}$ & 3 & 7 & 3 & 0.90 & 6.3 & 27 & 324 & 0.540 & 6.480 \\
\hline Desktop computer & $\begin{array}{l}80- \\
150 \mathrm{~W}\end{array}$ & 1 & 7 & 2 & 0.31 & 2.2 & 9 & 112 & 0.186 & 2.232 \\
\hline Laptop & $20-50 \mathrm{~W}$ & 2 & 7 & 2 & 0.18 & 1.3 & 5 & 65 & 0.108 & 1.296 \\
\hline Broadband router & $10 \mathrm{~W}$ & 1 & 7 & 18 & 0.18 & 1.3 & 5 & 65 & 0.108 & 1.296 \\
\hline Deep fryer & $1200 \mathrm{~W}$ & 1 & 2 & 1 & 1.20 & 2.4 & 10 & 123 & 0.206 & 2.469 \\
\hline Toaster & $\begin{array}{l}800- \\
1500 \mathrm{~W}\end{array}$ & 1 & 7 & 0.3 & 0.47 & 3.3 & 14 & 167 & 0.279 & 3.348 \\
\hline Window fan & $200 \mathrm{~W}$ & 2 & 7 & 2 & 0.80 & 5.6 & 24 & 288 & 0.480 & 5.760 \\
\hline Lights & $\begin{array}{l}100 w \\
\text { incan }\end{array}$ & 1 & 7 & 4 & 0.40 & 2.8 & 12 & 144 & 0.240 & 2.880 \\
\hline Lights & $\begin{array}{l}75 \mathrm{w} \\
\text { incan }\end{array}$ & 2 & 7 & 4 & 0.60 & 4.2 & 18 & 216 & 0.360 & 4.320 \\
\hline Lights & $\begin{array}{l}60 \mathrm{w} \\
\text { incan }\end{array}$ & 8 & 7 & 3 & 1.44 & 10.1 & 43 & 518 & 0.864 & 10.368 \\
\hline Lights & $\begin{array}{l}\text { 40W } \\
\text { Halogen }\end{array}$ & 14 & 7 & 6 & 3.36 & 23.5 & 101 & 1210 & 2.016 & 26.288 \\
\hline & & & & & 62.391 & 348.737 & 1494.587 & 17935.046 & 29.892 & 542.909 \\
\hline
\end{tabular}

